\title{
SOSYAL GÜVENLIK ALANINDA AB KATILIM ÖNCESI MALI YARDIMLARI
}

\section{INSTRUMENT FOR PRE ACCESSION ASSISTANCE ON SOCIAL SECURITY}

\section{Eyüp Serdar ERDOĞAN ${ }^{1}$}

\section{Özet}

Türkiye ile Avrupa Birliği'nin (AB) ilişkilerinin tarihi, 12 Eylül 1963 tarihinde imzalanan Ankara Antlaşması'na kadar uzanmaktadır. Yarım asırlık bu süre içinde birçok önemli gelişme olmuştur. Bugün Türkiye, $A B^{\prime} y e$ üyelik müzakerelerini sürdürmekte olan aday ülke konumundadır. $A B^{\prime}$ ye üye olmak için başvurmuş ve resmi olarak adaylığı tanınmış ülkelere $A B$ tarafindan özel mali destekler verilmektedir. 1999 yılı Helsinki Zirvesinde adaylık statüsü kazanan Türkiye "Katlım Öncesi Yardım Aracı" (Instrument for Pre-Accession Assistance-IPA) adı verilen artırılmış bir mali yardımdan faydalanmaktadır. Türkiye, 2001 yılından beri "Türk Mali Aracı" kapsamında, 2007 yılından itibaren ise IPA kapsamından olmak üzere $A B^{\prime}$ den katılım öncesi destek almaktadır. Bu çalışmada, AB'den IPA kanalıyla alınan yardımların sosyal güvenlik boyutu ele alınacaktır. AB projelerine kaynaklık eden IPA belgelerinin sosyal güvenliğe yaklaşımı ortaya konulmaya çalışılacak ve sosyal güvenlik alanında proje yapılabilecek alanlar belirtilecektir.

Anahtar Kelimeler: AB Mali Yardımları, AB Projeleri, Katılım Öncesi Mali Yardım Aracı (IPA) Çok-Yıllı Endikatif Planlama Belgesi (MIPD), Insan Kaynaklarının Geliştirilmesi Operasyonel Programı (iKG OP) IPA-I Geçiş Dönemi Desteği ve Kurumsal Yapılanma, IPA-IV İnsan Kaynaklarının Geliştirilmesi

\section{Abstract}

The history of Turkey and European Union relations lies to Ankara Agreement which was signed in 1963. Lots of developments have been

1 *Sosyal Güvenlik Uzman Yardımcısı, Sosyal Güvenlik Kurumu, Strateji Geliştirme Başkanlığı, eerdogan2@sgk.gov.tr 
occurred during this half century timeline. Today, Turkey is a candidate country which is negotiating full membership with EU. Special financial aid is being made by EU to countries which have been applied and accepted officially to EU for membership. Turkey which has been gained status of candidate country by Helsinki Summit in 1999 is benefitting from a special increased financial aid which is called Instrument for Pre-Accession Assistance (IPA). Turkey has been benefitting from PreAccession Assistance by Turkish Financial Instrument since 2001. After 2007, Turkey has been benefitting from new instrument called IPA. In this study, social security dimension of financial aids through IPA will be examined. Approach of IPA Documents, which is a source for EU Projects, to social security will be presented and possible project areas related to social security will be discussed.

Key Words: EU Financial Aid, EU Projects, Instrument for PreAccession Assistance, (IPA) Human Resources Development, Operational Programme (HRD OP), IPA-I-Transition Assistance and Institution Building Component, IPA IV-Human Resources Development Component

\section{Giriş}

Türkiye ile Avrupa Birliği'nin (AB) ilişkilerinin tarihi, 12 Eylül 1963 tarihinde imzalanan Ankara Antlaşması'na kadar uzanmaktadır. O zamanki adıyla Avrupa Ekonomik Topluluğu (AET) ile Türkiye Cumhuriyeti arasında imzalanan anlaşmanın temel amacı, Türkiye ve AET ülkelerindeki yaşam standartlarının; hızlandırılmış ekonomik gelişme, ticaretin düzenli genişlemesi ve Türkiye ekonomisi ile topluluk ekonomisi arasındaki farklılıkların giderilmesi sayesinde iyileştirilmesini sürekli kılmakt.. ${ }^{2}$ Yarım asırlık bu tarihçe içinde birçok önemli gelişme olmuştur. Aşağıdaki tabloda bu gelişim süreci kronolojik olarak verilmiştir. Bugün Türkiye $A B^{\prime}$ ye üyelik müzakerelerini sürdürmekte olan bir ülke konumundadır. Tablo 1'de bu tarihi gelişim görülebilir:

2 Avrupa Birliği Türkiye Delegasyonu, http://www.avrupa.info.tr/tr/ab-ve-turkiye.html 
Tablo 1: Türkiye'nin AB'ye Üyelik Süreci Kronolojisi

\section{Tarih Gelişme}

1987

1993

1996

1999

2001

2001

2004

2005

2005

2005

2007

2008
Türkiye 14 Nisan'da tam üyelik başvurusunu sundu.

$A B$ ve Türkiye "Gümrük Birliği" müzakereleri başladı.

Türkiye ve $A B$ arasındaki "Gümrük Birliği" 1 Ocak'ta yürürlüğe girdi.

Avrupa Konseyi, Komisyonun Türkiye hakkındaki ikinci Düzenli Raporundaki tavsiyelerine uyarak Aralık ayındaki Helsinki Zirvesinde Türkiye'ye $A B$ üyeliği için aday ülke statüsünü verdi.

Avrupa Konseyi 8 Mart tarihinde Türkiye'nin $A B$ katılım süreci için bir yol haritası sağlayan " $A B$ Türkiye Katılım Ortaklığı”nı kabul etti. 19 Mart'ta Türk Hükümeti, Katılım Ortaklığını yansıtan, Müktesebatın Üstlenilmesi için Ulusal Programı (NPAA) kabul etti.

Eylül ayındaki Kopenhag Zirvesinde, Avrupa Konseyi, şimdilerde "Katılım Öncesi Malî Yardım Aracı" olarak geçen mekanizma vasıtasıyla malî desteği kayda değer şekilde arttırmaya karar vermiştir.

Avrupa Konseyi 17 Aralık'ta Türkiye ile üyelik görüşmelerini başlatmaya karar verdi.

Türkiye'nin AB'ye katılım müzakereleri 3 Ekim'de başladı.

Ekim ayında, müktesebatla uyumun analitik incelemesi olan "Tarama Süreci" 35 başlık altında başladı.

Aralık'ta, Konsey Türkiye için yeni katılım ortaklığı belgesini kabul etti.

Kasım'da, Avrupa Komisyonu Türkiye ile katılım müzakereleri hakkında Konsey'e ilerleme raporunu sundu.

Avrupa Komisyonu Kasım ayında Türkiye'nin $A B^{\prime}$ ye katılımı ile ilgili yıllık ilerleme raporunu yayınladı.

Kaynak: Avrupa Birliği Türkiye Delegasyonu, http://www.avrupa.info.tr/tr/ab-ve-turkiye.html 
$A B$ günümüzde, insan hakları ve pazar ekonomisi konusunda ortak değerleri paylaşan 28 üye ülkeden oluşmaktadır. Gerek bu ülkelerin içeride ekonomik ve sosyal gelişmelerine destek olmak gerekse ülkelerarası gelişmişlik düzeyini dengelemek amacıyla hibe ya da kredi şeklindeki çeşitli mali araçlar halinde önemli miktarlarda kaynak harcamaktadır. $A B$, aynı zamanda gerekli gördüğü hallerde üçüncü ülkelere de mali yardımlarda bulunmaktadır.

Bu ülkelerin yanısıra, $A B^{\prime}$ ye üye olmak için başvuran ve resmi olarak adaylı̆ıı tanınmış ülkelere de özel mali destekler verilmektedir. 1999 yılı Helsinki Zirvesinde adaylık statüsü kazanan Türkiye ile birlikte mevcut dört aday ülke statüsünde olan İzlanda, Makedonya, Karadağ, Türkiye "Katılım Öncesi Yardım Aracı" (Instrument for Pre-Accession AssistanceIPA) adı verilen artırımış bir mali yardımdan faydalanmaktadır. Ayrıca henüz adaylık statüsünü elde edememiş durumda olmakla birlikte, Avrupa'da yer alan ve adaylığı çok kısa vadede intimal dahilinde bulunan dört potansiyel aday ülke statüsündeki Arnavutluk, Bosna Hersek, Sırbistan ve Kosova da paralel bir mali yardım kapsamına girmektedir. Söz konusu yardımlar, ülkelere $A B$ üyeliği süreci kapsamında $A B$ müktesebatına uyum ve uygulama yönünde ülke tarafindan alınması gereken siyasi, ekonomik, yasal ve idari tedbirler için mali kaynak sunmaktadır.

Haziran 1993 tarihindeki Kopenhag Zirvesi'nde Avrupa Konseyi, Orta ve Doğu Avrupa ülkelerine üç temel kriteri yerine getirdiklerinde Avrupa Birliği'ne katılma hakkı tanınacağını karara bağlanmıştr.. ${ }^{3} \mathrm{Bu}$ kriterler, Kopenhag Zirvesi'nde belirlendiği için literatüre "Kopenhag Kriterleri” adı altında geçmiştir. Söz konusu kriterler aşağıda Şekil 1'de gösterilmiştir.

Kopenhag Kriterleri, aday ülkelerin kademeli ve uyumlu bir bütünleşmeyi sağlayan koşulları yaratmak için idari yapılarını uyumlu hale getirmelerinin öneminin vurgulandığı Madrid Avrupa Konseyi

3 Avrupa Birliği Türkiye Delegasyonu, http://www.avrupa.info.tr/tr/ab-mali-destegi/neden-ab-mali-destegi/ ueyelik-kriterleri-kopenhag-kriterleri.html 
toplantısında Aralık 1995'te onaylanmıştır.

$A B$ 'den sağlanan yardımlar da Kopenhag Kriterleri'ne paralel olarak, hukukun üstünlüğü ve hayata geçirilmesi de dahil olmak üzere demokratik kurumların güçlendirilmesi, insan hakları ve temel özgürlüklerin yaygınlaştırılması ve korunması, azınlık haklarına saygı, toplumsal cinsiyet eşitliğinin yaygınlaştrılması ve ayrımcılı̆ıın yasaklanması; kamu yönetimi reformu; sivil toplumun geliştirilmesi; sosyal dışlanmayla mücadele; uzlaşı, güven tesisi ve yeniden yapılanma; bölgesel ve sınır ötesi yardım alanlarında kullanılmaktadır. ${ }^{4} 2007$ yılında, aday ve potansiyel aday ülkelere yapılan tüm mali yardımlar IPA adı altında birleştirilmiştir.

\section{Şekil 1: Kopenhag Kriterleri}

\section{Siyasi Kriterler: "Hukukun üstünlüğ̈̈, insan} haklarl ve azinliklara saygl ve demokrasiyi garanti altına alan kurumsal istikrar"

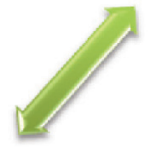

yen bir pazar

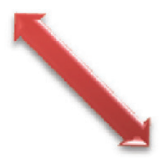

AB Müktesebatı ile Uyum Kriterleri: "Avrupa birliği'nin, siyasi, ekonomik ve parasal birlik amaçlarına bağlılık"

Kaynak: Avrupa Birliği Türkiye Delegasyonu, http://www.avrupa.info.tr/tr/ab-mali-destegi/neden-ab-malidestegi/ueyelik-kriterleri-kopenhag-kriterleri.html

Bu çalışmanın amacı $A B^{\prime}$ nin, aday ülke statüsünde bulunan Türkiye'ye IPA adı altında yapılan mali yardımların niteliğini ve niceliğini ortaya koymaktr. Özellikle sosyal politika ve sosyal güvenlik alanında yapılan yardımların niteliği, kullanım amacı, bir nihai faydalanıcı olarak Sosyal Güvenlik Kurumu'nun (SGK) bu yardımları hangi alanlarda kullanabileceği ortaya konulmaya çalışılacaktır.

4 A new focus to EU assistance for enlargement, European Commission,2009, s. 6

http://ec.europa.eu/enlargement/pdf/publication/ipa_brochure_2009_en.pdf 


\section{AB Mali Yardımları}

Türkiye'ye yönelik $A B$ mali desteğinin başlangıçtaki temel amacı, Avrupa içinde ve dışında barış, istikrar ve refah alanının genişletilmesi olmuştur. $A B^{\prime}$ nin Türkiye'yi bir aday olarak kabul etmesiyle birlikte, mali destek Türkiye'nin $A B$ üyeliğine hazırlanmasına odaklanmıştır. Ayrıca mali yardımlar, Türkiye'nin gelecekteki üyeliği konusunda Birliğin kararlılığını göstermektedir. ${ }^{5}$ AB Mali Yardımlarının mevcut öncelikleri, Türkiye'de reformu, sınır ötesi işbirliğini ve üye ülkelerle ortaklığı desteklemektedir.

Türkiye, 2001 yılından beri Türk Mali Aracı kapsamında AB'den katılım öncesi destek almaktadır. Fonlar her yıl ulusal programlar kapsamında yıllık bazda programlanmaktadır. 2007 itibariyle Türkiye için bu katılım öncesi Mali Araç, hem aday hem de potansiyel aday ülkeler için katlım öncesi destek sağlayan Katılım Öncesi Mali Yardım Aracı (IPA) ile değiştirilmiştir. IPA ile yeni alanlarda mali destek sağlanması hedeflenmiştir.

$A B$ Mali Yardımları tartışılırken, $A B^{\prime}$ nin sağladığı bu mali kaynağın nereden geldiği konusunda akıllarda soru işareti oluşmaktadır. Bu mali yardımların kaynağı $A B$ bütçesi olup, bütçenin hazırlanmasında, daha önce kabul edilmiş olan çok yıllı mali planlar temel teşkil etmektedir. $A B^{\prime}$ nin tıpkı bir ulusal devlet gibi olan bütçesinde gelirler ve giderler yer almaktadır. Gelirler, üye devletlerin Gayri Safi Milli Hasılaları üzerinden alınan payların yanında, $A B^{\prime}$ nin bazı alanlardan pay aldığı vergi gelirleri ve diğer gelirlerden oluşmaktadır. Giderler ise Mali Planlar aracılığıyla yapılmaktadır. AB'de en son kabul edilen Mali Plan, 4. Mali Plandır. Bu Mali Plan 2007-2013 dönemi içinde kalan 7 yılı kapsamaktadır. Bir sonraki mali plan ise 2014-2020 yılları arasını kapsayacaktı.

Mali Planlar, Çok Yıllı Finansal Çerçeve Belgeleri aracılığıyla oluşturulmaktadır. Çerçeve Belgeleri, AB'nin 7 yıllık bütçesi olmayıp $A B^{\prime} n$ in harcamalarını tahmin edilebilir kılmakta ve aynı zamanda bütçenin kat bir disiplin içerisinde kalmasını sağlamaktadır. Çerçeve

5 Avrupa Birliği Türkiye Delegasyonu, http://www.avrupa.info.tr/tr/funding-opportunities/priorities.html 
Belgeleri büyük harcama alanları için tavan miktarları belirlemektedir. $A B$ Parlamentosu ve $A B$ Konseyi bütçe konusunda birlikte otorite olup bütçe her yıl için ayrı ayrı belirlenmektedir. Aslında, Çerçeve Belgeleri belirlenecek yıllık bütçeler için bir tavan oluşturmakta ve yıllık bütçeler her zaman bu tavanın altında belirlenmektedir. Çerçeve Belgeleri, de facto olarak gelecek yıllar için politik öncelikleri ortaya koymaktadır. ${ }^{6}$

Kabul edilip uygulamaya konulan planlar, imzalandıkları yılda geçerli olan fiyat seviyesine göre düzenlendikleri için gelecek yıllardaki enflasyon oranları bütçe rakamlarına yansıtılmaktadır. Bu nedenle rakamlar, o yılların enflasyon oranları ölçüsünde büyümektedir. Ayrıca AB'nin toplam Gayri Safi Milli Hasılasının (GSMH) belli bir yüzdesini temsil eden öz kaynak tavan değerlerini bulmak için de her yılın güncel milli gelir verilerine bakılması gerekmektedir. ${ }^{7}$

2007-2013 döneminin 7 yıllık rakamlarını içeren Mali Bütçe, uzun tartışmaların ardından 15-16 Aralık 2005 tarihinde yapılan AB Zirve Toplantısında kabul edilmiştir. Bu anlaşma ile 7 yıl için üye ülkelerin GSMG'lerinin \%1,045'ine karşılık gelen 862,363 milyar avro üzerinde uzlaşılmıştır. $^{8}$ 4. Mali Plan temel olarak rekabetçiliğin geliştirilmesi, bütünleşme, sürdürülebilir kalkınma, Avrupa vatandaşlığı, $A B^{\prime}$ nin dış politikası üzerine yoğunlaşmıştır. Bu konuların yanında Mali Plan, doğru kaynak ayırımını, finansal sistemi ve iyi yönetimi ilke edinmiştir.

Sürdürülebilir Kalkınma, Sürdürülebilir Yönetim ve Doğal Kaynakların Korunması, Vatandaşlık, Özgürlük, Güvenlik ve Adalet, Küresel Bir Aktör Olarak $A B$ ve Yönetim başlıkları altında ayrılmış kaynaklar toplamı 1,025 milyar Avrodur.

"Küresel Bir Aktör Olarak AB" başlığı, katılım öncesi enstrümanları da içerecek şekilde tüm dış eylemleri kapsamaktadır. IPA yardımları da bu başlık altında yapılmaktadır. Bu alana 2007-2013 yılları için 56,8 Milyar Avro kaynak ayrılmış olup 2014-2020 yıllarını kapsayacak 5. Mali Planda bu miktarın 58,7 Milyar Avroya çıkarılması öngörülmüştür. ${ }^{9}$

6 European Commission proposal for the 2014-2020 Multiannual Financial Framework, s. 3 http://ec.europa. eu/budget/library/biblio/publications/2011/mff2011/MFF_2011_en.pdf

7 Erişim ( 20.12.2012) Nurettin Bilici, Avrupa Birliği ve Türkiye s. 139-140

8 Nurettin Bilici, a.g.e. s. 141

9 Avrupa Komisyonu, http://ec.europa.eu/budget/mff/index_en.cfm 


\section{Katılım Öncesi Mali Yardım Aracı (IPA)}

IPA'nın temel amacı aday ülkenin $A B^{\prime} y e$ üye olma yolundaki intiyaç ve önceliklerine hizmet eden projelerin desteklenmesidir. Projeler aracılı̆̆ıyla kullandırılan fonlar, $A B$ müktesebatına uyumu ve bu uyum için gerekli idari kapasitenin oluşturulmasını hedeflemektedir. Bununla beraber ekonomik ve sosyal uyumun sağlanmasına yönelik projeler de mali yardımlar içerisinde gün geçtikçe artmaktadır. IPA ülkelerin ihtiyaçlarını esas almaktadır, bu nedenle yardımların önceliği yapılan analizlere göre tespit edilmektedir. Buradaki kilit öğeler; $A B^{\prime}$ nin yararlanıcı ülkelerle kurduğu Kathlım/Avrupa Ortaklıkları, Komisyon'un genişleme strateji belgesi ve her ülke hakkında hazırlanan ilerleme raporlarıdır. Yardımların dağıtılmasında ülkelerin fonları kullanma ve idare etme kapasitesi ile katılım şartlarına ne kadar uydukları gibi kriterler dikkate alınmaktadır. Söz konusu koşullar sağlanmadığında yardımların askıya alınması hükümleri uygulanabilmektedir. Böylece IPA, genişlemenin siyasi çerçevesi ile $A B$ bütçe süreci arasında bağ kurmuş olmaktadır.

IPA bileşenlerinin programlanması ve önceliklerin belirlenmesinde $A B$ mali yardımının hangi sektörlerde kullanılabileceğine işaret eden ana belge "Çok Yıllı Endikatif Planlama Belgesi"dir (Multi-Annual Indicative Planning Document - MIPD). Söz konusu belge 3 yıllık dönemler için hazırlanmakta ve ülkemizin katkılarıyla Avrupa Komisyonunca yıllık olarak revize edilmektedir. Komisyonun yeni yaklaşımı çerçevesinde, 2011-2013 dönemiyle birlikte uygulanacak projelerin, MIPD'de belirlenen öncelikli sektörlerde yoğunlaşması hedeflenmiştir. Bu yaklaşımın amacı kısıtlı kaynakların daha özel alanlarda kullanılarak projelerin etkilerinin ve sonuçlarının çok daha hissedilir ve görünür hale getirilmesidir. Çalışmanın ilerleyen kısımlarında MIPD daha ayrıntılı olarak ele alınacaktır.

2007 yılında aday ve potansiyel aday ülkelere yapılan tüm mali yardımlar IPA adı altında birleştirilmiştir. Beş bölüm halinde yapılandırılan IPA, geçiş dönemi ve kurumsal yapılanma desteğinin yanı sıra çevre, ulaştırma, bölgesel rekabet, insan kaynaklarının geliştirilmesi 
ve kırsal kalkınma olarak belirlenen yeni alanlarda katlım öncesi mali destek sağlamaktadır. Ayrıca aday ülkeler, katkı payları kısmen IPA altında finanse edilmekte olan Topluluk Programlarına katılmaya devam etmektedir. IPA Bileşenleri 5 başlık altında toplanmıştır. Başlıklar aşağıda yer alan Şekil 2'de gösterilmiştir.

\section{Şekil 2: IPA Bileşenleri}

\begin{tabular}{ll} 
& $\begin{array}{l}\text { I. Geçiş Dönemi Desteği ve Kurumsal Yapılanma } \\
\text { II. Sınır Ötesi İşbirliği }\end{array}$ \\
\cline { 2 - 2 } & III. Bölgesel Kalkınma \\
\hline IV. İnsan Kaynaklarının Geliştirilmesi \\
\hline V. Kırsal Kalkınma (IPARD) \\
\hline
\end{tabular}

IPA kapsamında 2007-2013 yılları itibarıly bütçelenen toplam fon yaklaşık 10,1 milyar avro tutarındadır. Bu tutarın yaklaşık yarısını oluşturan 4,9 milyar avro, nüfus ve yüzölçümü büyüklüğü dikkate alınarak Türkiye için ayrılmış durumdadır. ${ }^{10}$ Bu durum Tablo 2'de görülmektedir.

Tablo 2: IPA Dönemi (2007-2013) Türkiye Mali Yardım Miktarları (milyon avro)

\begin{tabular}{|ccccccccc|}
\hline BILEŞEN & $\mathbf{2 0 0 7}$ & $\mathbf{2 0 0 8}$ & $\mathbf{2 0 0 9}$ & $\mathbf{2 0 1 0}$ & $\mathbf{2 0 1 1}$ & $\mathbf{2 0 1 2}$ & $\mathbf{2 0 1 3}$ & TOPLAM \\
\hline I. Geçiş Dönemi Desteği ve Kurumsal Yapılanma & 256,7 & 256,1 & 239,6 & 211,3 & 228,6 & 233,9 & 238,3 & $1.664,50$ \\
\hline II. Sınır Ötesi İșbirliği & 2,1 & 2,9 & 3 & 9,6 & 9,8 & 10 & 10,2 & 47,5 \\
\hline III. Bölgesel Kalkınma & 167,5 & 173,8 & 182,7 & 238,1 & 293,4 & 367,8 & 378 & $1.801,30$ \\
\hline IV. İnsan Kaynaklarının Geliștirilmesi & 50,2 & 52,9 & 55,6 & 63,4 & 77,6 & 89,9 & 96 & 485,6 \\
\hline V. Kırsal Kalkınma & 20,7 & 53 & 85,5 & 131,3 & 172,5 & 197,9 & 213 & 873,9 \\
\hline TOPLAM & $\mathbf{4 9 7 , 2}$ & $\mathbf{5 3 8 , 7}$ & $\mathbf{5 6 6 , 4}$ & $\mathbf{6 5 3 , 7}$ & $\mathbf{7 8 1 , 9}$ & $\mathbf{8 9 9 , 5}$ & $\mathbf{9 3 5 , 5}$ & $\mathbf{4 . 8 7 2 , 9 0}$ \\
\hline
\end{tabular}

Kaynak: AB Bakanlığı ( http://www.abgs.gov.tr/index.php?p=5 )

10 Avrupa Birliği Bakanlığı, http://www.abgs.gov.tr/index.php?p=5 
Yeni mali yardım yaklaşımının hedeflerinden biri de, sonuçları daha görünür ve hissedilir projelerin uygulanması yoluyla tartşmaları ilerleyen aylarda başlayacak olan 2014-2020 AB bütçesinde ülkemize ayrılan payın daha da artııımasıdır. Ülkemizin 2007-2010 döneminde sergilediği ve 2011-2013 döneminde sergileyeceği performans, hem yapılacak fon tahsisat hem de genel anlamda Türkiye'nin AB'ye üyeliği konusunda üye ülke kanaatlerini olumlu yönde etkileyecektir. ${ }^{11}$

\subsection{IPA Fonlarının Kullanımı}

Aday ülkeler için $A B$ finansman döngüsü aşağıdaki adımları kapsamaktadır:12

a) Bütçe kararı: $A B$ tarafindan ilgili ülkeye tahsis edilecek miktarın kararı Brüksel'de $A B$ üye ülkeleri tarafindan ülkenin büyüklüğü, nüfusu gibi çeşitli faktörler ve belli alanlardaki reform gereksinimlerine göre alınmaktadır.

b) Fonların ulusal programlara dağıımı: Avrupa Komisyonu ve Türkiye'nin ortak kararıyla, katılım için öncelikli yatırım ihtiyaçları, finansman için sunulan sektörel önergelerin kalitesi, $A B$ finansmanı için başvuran Bakanlıkların uygulama kapasitesi gibi faktörler göz önünde bulundurularak alınmaktadır. Her kısım için fonların dağıım işlemine programlama adı verilmektedir. Programlamanın aşamaları, aşağıda yer alan Şekil 3'te gösterilmiştir:

11 Avrupa Birliği Bakanlığı, http://www.abgs.gov.tr/index.php?p=5

12 Avrupa Birliği Türkiye Delegasyonu,

http://www.avrupa.info.tr/tr/funding-opportunities/how-to-apply.html 


\section{Şekil 3: Programlama Aşamaları}

1. Türk Kamu Kuruluşları proje fikirlerini $A B$ Bakanlığı'na sunar

2. AB Bakanlığı ve Avrupa Komisyonu'nun Genişlemeden Sorumlu Genel Müdürlüğü'nün ortak kararıyla seçilen proje fikirleri kapsamlı şekilde geliştirilir.

3. Türk Kamu Kuruluşları detaylı proje teklifleri hazırlar.

4. Türk Hükümeti ve Avrupa Komisyonu bu projeler için fon dağılımını yapar.

Ulusal program, belirli alanlarda reform gereksinimlerini destekleyen çeşitli projelerden oluşmaktadır. $A B$ finansmanı genellikle projelerin toplam bedelinin $\% 75$ 'ini kapsamakta, fakat bazı özel projelerde $A B$ finansmanı \%100'e erişebilmektedir. Ulusal Programın imzalanmasını takiben, projelerin uygulaması ihale süreci ile başlar. Türk Kamu Sisteminde ihale ve ödeme sürecinden Merkezi Finans ve ihale Birimi (MFiB) sorumludur. Bu fonların ihale edilmesinde rekabet ortamının yaratılması $A B$ kamu satın alma prosedürlerine göre yapılmaktadır. Başarılı başvuru/teklif sahipleriyle, projelerin uygulanması için üstlendikleri aktiviteler kapsamında, sözleşmeler imzalanmaktadır. Şeffaflık ve eşit muamelenin sağlanması için ihaleler ve teklif çağrıları düzenli olarak $A B$ Komisyonu, $A B$ Bakanlığı ve MFiB' nin web sitelerinde yayınlanmaktadır. ${ }^{13}$

13 ilgili web siteleri için bkz:

http://ec.europa.eu/

http://www.avrupa.info.tr/

http://www.mfib.gov.tr/ 
c) Fonların ödenmesi: Projelerin zamanında, doğru ve başarılı biçimde uygulanmasını takiben, yüklenicilere MFiB tarafindan ödemeleri yapılmaktadır. Bu ödemeler ancak yüklenicilerin yükümlülüklerini yerine getirmeleri ve $A B$ satın alma kurallarına uymaları koşuluyla yapılmaktadır. Türkiye'de $A B$ fonlarının kullanılmasının sorumluluğu Türk Hükümeti'nin elindedir. Bununla beraber Avrupa Komisyonu tüm ihale sürecinde $A B$ prosedürlerinin izlenmesini sağlamaktadır. Bu nedenle Avrupa Komisyonu'nu temsilen, Avrupa Birliği Türkiye Delegasyonu, her projenin ihale ve sözleşme aşamasında önceden onay vermektedir. ${ }^{14}$

IPA kapsamındaki mali yardımlardan faydalanabilmek için, yararlanıcı ülkenin gerekli idari yapılarının oluşturması zorunludur. Bu idari yapılar ve bunların fonksiyonları, IPA Uygulama Tüzüğünde açıklanmaktadır. ${ }^{15}$ Yararlanıcı ülke, bu idari birim ve otoriteler arasında görevler ayrımını sağlamakla yükümlüdür. Söz konusu birim ve otoriteler kurulup işlemeye başladıktan sonra $A B$, yardım fonları üzerindeki yönetim yetkisini yararlanıcı ülkeye devretmektedir. IPA programlarının, sağlıklı mali yönetim prensibine uygun olarak yönetiminden ve uygulanmasından IPA bileşeni veya programı itibarıyla bir "Program Otoritesi" sorumludur. Program Otoritesi ihaleye çıkma, sözleşme yapma, ödeme ve raporlama yapmakla görevlendirilmiştir. Türkiye'de IPA'nın I. Bileşeni olan "Geçiş Dönemi Desteği ve Kurumsal Yapılanma" ile ilgili program otoritesi olarak AB Bakanlığı, 4. Bileşeni olan 'Insan Kaynaklarının Geliştirilmesi' ile ilgili program otoritesi olarak ise Çalışma ve Sosyal Güvenlik Bakanlığı (ÇSGB) belirlenmiştir. ${ }^{16}$

14 Avrupa Birliği Türkiye Delegasyonu, http://www.avrupa.info.tr/tr/funding-opportunities/how-to-apply.html 15 Ayrıntılı bilgi için bkz: 1085/2006 sayılı Konsey Tüzüğünün uygulanmasına ilişkin 12 Haziran 2007 tarihli ve 718/2007 sayılı Komisyon Tüzüğü: http://eurlex.europa.eu/smartapi/cgi/sga_doc?smartapi!celexplus!prod! DocNumber\&lg=en\&type_doc=Regulation\&an_doc $=2007 \& n u \_d o c=718$

16 Ayrıntllı bilgi için bkz: http://ikg.gov.tr/web/ 


\subsection{IPA Sözleşme Türleri}

IPA kapsamında dağıttlan mali yardım, sözleşmeler eli ile yapılmaktadır. Sözleşmeler beş çeşittir: Hizmet Sözleşmeleri, Mal Alım Sözleşmeleri, inşaat Sözleşmeleri, Hibeler ve Eşleştirme.

Şekil 4: IPA Sözleşmeleri

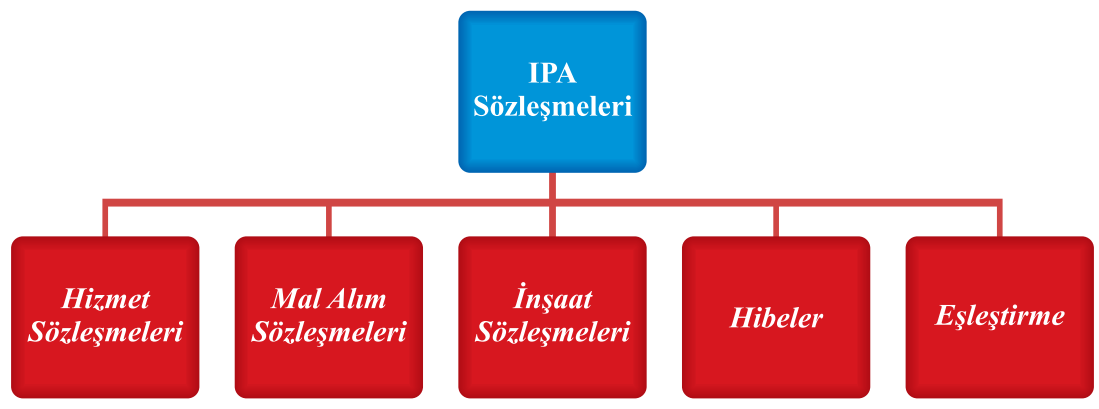

\subsubsection{Hizmet Sözleşmeleri}

Hizmet Sözleşmeleri, IPA kapsamında danışmanlık, araştırma, teknik bilgi ve eğitim hizmetleri için kullanılmaktadır. Hizmetler, genellikle sınırlı sayıda şirketin (kısa listeye giren) teklif sunmaya çağrıldığı, Uluslararası Sınırlı ihale Usulü ile sözleşmeye bağlanmaktadır. 300.000 Avro üzerinde hizmet alımı için uygulanan ihale usulüdür. Tutarı 20.000300.000 Avro arasındaki hizmet sözleşmeleri çerçeve sözleşme ya da rekabete dayalı müzakere usulüne göre ihale edilmektedir. Rekabete dayalı müzakere usulünde en az üç adaya ihaleye çağrı mektubu gönderilmektedir. ${ }^{17}$

Tutarı 20.000 Avro ya da daha az olan sözleşmeler doğrudan temin yoluyla ihale edilebilmektedir. Tutarı 2500 Avro'dan az olan sözleşmelerde Sözleşme Makamı bir ihalenin ön kabulü olmaksızın faturaya dayalı olarak ödeme yapabilmektedir. ${ }^{18}$

17 Avrupa Birliği Türkiye Delegasyonu, http://www.avrupa.info.tr/tr/avrupa-takimi/nasil-uygulanir/hizmetsoezlesmeleri.html

18 Daha fazla bilgi için bkz:

http://www.avrupa.info.tr/tr/avrupa-takimi/nasil-uygulanir/hizmet-soezlesmeleri.html 


\subsubsection{Mal Alım Sözleşmeleri}

Mal alım prosedürleri, Avrupa Komisyonu tarafindan yapılacak mal alımlarında kullanılan satın alma prosedürlerinin bir parçasıdır. Bu sözleşmeler malların satın alınması, finansal kiralanması (leasing), kiralanması veya ödünç alınmasını içermektedir. Mal alımları için uygulanan prosedürler sözleşmenin tahmini değerine göre değişmektedir. ${ }^{19}$

300,000 Euro'nun üzerinde bütçeye sahip sözleşmeler için Uluslararası Açık ihale'ye çıkılmaktadır. Değeri 100,000 Euro'dan yüksek ve 300,000 Euro'dan düşük mal alımı sözleşmeleri için açık yerel ihale yapılmaktadır. Değeri 100,000 Euro'nun altındaki mal alımı sözleşmeleri, rekabetçi pazarlık usulü ile ihale edilmektedir. Değeri 20000 Euro'nun altında veya 20000 Euro olan sözleşmeler, doğrudan temin usulüyle ihale edilebilmekte olup tutarı 2500 Avro'dan az olan sözleşmelerde Sözleşme Makamı bir ihalenin ön kabulü olmaksızın faturaya dayalı olarak ödeme yapabilmektedir. ${ }^{20}$

\subsubsection{Inşaat Sözleşmeleri}

Inş̧aat sözleşmeleri, proje ve bina veya kültürel binaların onarımı, yapısal işler, tesisat, elektrik ve mekanik tesisler ile attk su arıtma tesislerinin kurulumu gibi her türlü inşaat mühendisliği işi için kullanılmaktadır. $A B$ fonları normalde ulusal finansmanla birlikte yerel bayındırlık işleri için ortak finansman olarak sağlanmaktadır. Büyük çaplı işlerde Avrupa Yatırım Bankası (AYB) veya Dünya Bankası gibi bir veya birden fazla uluslararası finans kuruluşundan da ortak finansman desteği alınabilmektedir. ${ }^{21}$

Yapılacak işin değerinin 5,000,000 Avro veya üzerinde olması halinde Uluslararası Açık ihale Usulünün izlenmesi gerekmektedir. Bazı işlerin spesifiközellikleridikkate alınarakSınırlı ihale Usulü kullanılabilmektedir.

19 Avrupa Birliği Türkiye Delegasyonu,

http://www.avrupa.info.tr/tr/avrupa-takimi/nasil-uygulanir/supply-contracts.html

20 Daha fazla bilgi için bkz:

http://www.avrupa.info.tr/tr/avrupa-takimi/nasil-uygulanir/supply-contracts.html

21 Avrupa Birliği Türkiye Delegasyonu,

http://www.avrupa.info.tr/tr/ab-mali-destegi/nasil-uygulanir/yapim-soezlesmeleri.html 
Değeri 300,000-5,000,000 Avro arasında olan işler için Yerel Açık İhale Usulü izlenmektedir. Değeri 20,000-300,000 Avro arasında olan işler için Rekabete Dayalı Müzakere Usulü izlenmektedir. Değeri 20,000 Euro'dan az olan işler için Doğrudan Temin Usulü kullanılabilmektedir. ${ }^{22}$

\subsubsection{Hibeler}

Hibeler AB politikalarına katkı sağlayan faaliyetler yürüten üçüncü taraf yararlanıcılara (genellikle kar amacı gütmeyen kuruluşlara) verilen mali bağışlardır. Avrupa Komisyonu hibe yoluyla ya dış bir kuruluş tarafindan yürütülen bir projeye/eyleme (proje hibesi) veya faaliyetleri Birliğin politika hedeflerine katkı sağlayan ya da AB politikalarıyla ilgili bir amaç güden kuruluşlara (Operasyonel Hibe) doğrudan katkı sağlamaktadır.

Hibeler bir programa eş-finansman sağlamaktadır; başvuranlardan proje maliyetinin bir kısmını kendilerinin karşılaması beklenmektedir. Yerel veya uluslararası teklif çağrısı yoluyla doğrudan hibe kullandırılması kararı çağrının türüne ve tutarına bağlı olarak değişmektedir. ${ }^{23}$

\subsubsection{Eşleştirme}

Eşleştirme, Türkiye ile $A B$ 'deki kamu yönetimi ve yasaların yürürlüğe konması ve uygulanması alanında en iyi uygulamaları paylaşmak için tasarlanmış bir $\mathrm{AB}$ aracıdır. Üye ve aday ülkeler bir araya gelerek mevzuatlarını karşılaştırmakta ve uyum sağlanması gereken alanları belirlemektedir. ${ }^{24}$

Türkiye'deki kurumlar tarafindan eşleştirme 2002 yılından beri kullanılmaktadır. Genellikle polislerin eğitimi, sığınma ve göç politikaları gibi adalet ve içişlerinin yanısıra tarım, enerji ve çevre alanlarına da yoğunlaşılmıştır. Eşleştirme projelerinde bir karşılaştırma süreci vardır. $A B$ mevzuat ile uzun dönem tecrübesi olmuş üye ülkelerle ya da aynı dönemi yaşayacak yararlanıcı ülke gibi bu dönemi yeni geçirmiş yeni

22 Daha fazla bilgi için bkz:

http://www.avrupa.info.tr/tr/ab-mali-destegi/nasil-uygulanir/yapim-soezlesmeleri.html

23 Avrupa Birliği Türkiye Delegasyonu,

http://www.avrupa.info.tr/tr/avrupa-takimi/nasil-uygulanir/hibeler.html

24 Avrupa Birliği Türkiye Delegasyonu,

http://www.avrupa.info.tr/tr/avrupa-takimi/nasil-uygulanir/eslestirme.html 
üye ülkeler ile mevzuat karşılaştırılması yapılmaktadır. ${ }^{25}$

\section{3. Çok-Yıllı Endikatif Planlama Belgesi (MIPD) 2011-2013}

Çok Yıllı Endikatif Planlama Belgesi'nin (MIPD) amacı, 2011-2013 programlama döneminde Türkiye'ye sağlanacak mali yardımlar için AB önceliklerinin belirlenmesidir. MIPD'ler, cari ilerleme raporu (9 Kasım 2010'da Genişleme Paketi'nin parçası olarak kabul edilmiştir), ilgili ülkenin Katılım Ortaklığı belgesinde tanımlanan ihtiyaçlar ile ülkenin kendi stratejilerini esas almaktadır. Söz konusu belge, Türk Hükümeti, yerel paydaşlar, $A B$ üye ülkeleri ve donör kuruluşlarla istişarelerde bulunularak oluşturulmuştur.

Son dönemlerde $A B$ Komisyonu, bu sürecin stratejik niteliğinin geliştirilmesine ve ilerleme raporlarında belirtilen önceliklerle mali yardımların programlaması arasındaki bağlantının güçlendirilmesine yönelik bir takım tedbirler almıştır. Bu vurguyu daha iyi resmetmek ve yararlanıcı ülkelerin sahipliliğini kuvvetlendirmek için Komisyon, katılım öncesi yardımların planlamasında sektör odaklı yaklaşımın benimsenmesini önermektedir. ${ }^{26}$

IPA yardımlarının etkisini arttırmak ve daha gerçekçi ve ulaşılabilir sonuçlara odaklanmak için Komisyon, çabalarını belirli sektörlere yoğunlaştırmaya karar vermiştir. Sektörel yaklaşım ile gerektiğinde ulusal otoritelerin öncülüğünde, hem mükerrer çabaları önleyerek hem de daha fazla etkinlik ile etkililik sağlayarak yararlanıcılar ve donör kuruluşlar arasında işbirliğinin gelişimine yol açacaktır. Bu yolla tüm paydaşlar, müşterek çabaların nihai etkilerine giderek daha fazla odaklanmış olacaklardır. ${ }^{27}$

IPA yararlanıcısı ülkeler tarafindan geliştirilmiş sınırlı sayıda sektör programı bulunmaktadır. Buna rağmen artık öncelikli sektörlere odaklanmaya başlayarak Komisyon, AB ve diğer donör yardımları üzerine

25 Daha fazla bilgi için bkz:

http://www.avrupa.info.tr/tr/avrupa-takimi/nasil-uygulanir/eslestirme.html

26 Çok-Yılıı Endikatif Planlama Belgesi (MIPD) 2011-2013, AB Bakanlığı Gayrı Raesmi Türkçe Çeviri, s. 3

27 Çok-Yılı Endikatif Planlama Belgesi (MIPD) 2011-2013, AB Bakanlığı Gayrı Resmi Türkçe Çeviri, s. 3 
inşa edilebilecek bu tür programların gelişimini destekleyebilecektir. MIPD' nin kapsadığı dönemde IPA yardımı için belirlenen öncelikler aşağıda belirtildiği gibidir:

- Türkiye için ilk öncelik, hukukun üstünlüğü gibi hassas bir alan kapsamında ilerleme kaydedebilmek amacıyla kilit nitelik arz eden adalet ve temel haklara müteallik reformların gerçekleştirilmesidir. Bu alanda amaç, yargı ve temel haklar alanlarında kilit nitelik arz eden reformların gerçekleştirilmesi adına hukukun üstünlüğü gibi kritik alanlarında ilerleme kaydedilmesidir.

- Ikinci öncelik, ulaştrma, tarım, gıda güvenliği, çevre, iklim değişikliği ve enerji gibi, $A B$ standartlarının benimsenmesinin karmaşık mevzuat veya yüksek maliyetli tedbirlerin hayata geçirilmesinin gerekli olduğu alanlarda müktesebat uyumunu sağlamaktır.

- Üçüncü öncelik, Türkiye'nin ekonomik ve sosyal gelişiminin desteklenmesi ve rekabet edebilirliğinin arttırımasıdır.

Ortak ilgi alanına giren konular olarak desteklenecek yatay öncelikler aşağıdaki tabloda gösterilmiştir: 
Şekil 5: MIPD Belgesinin Yatay Öncelikleri

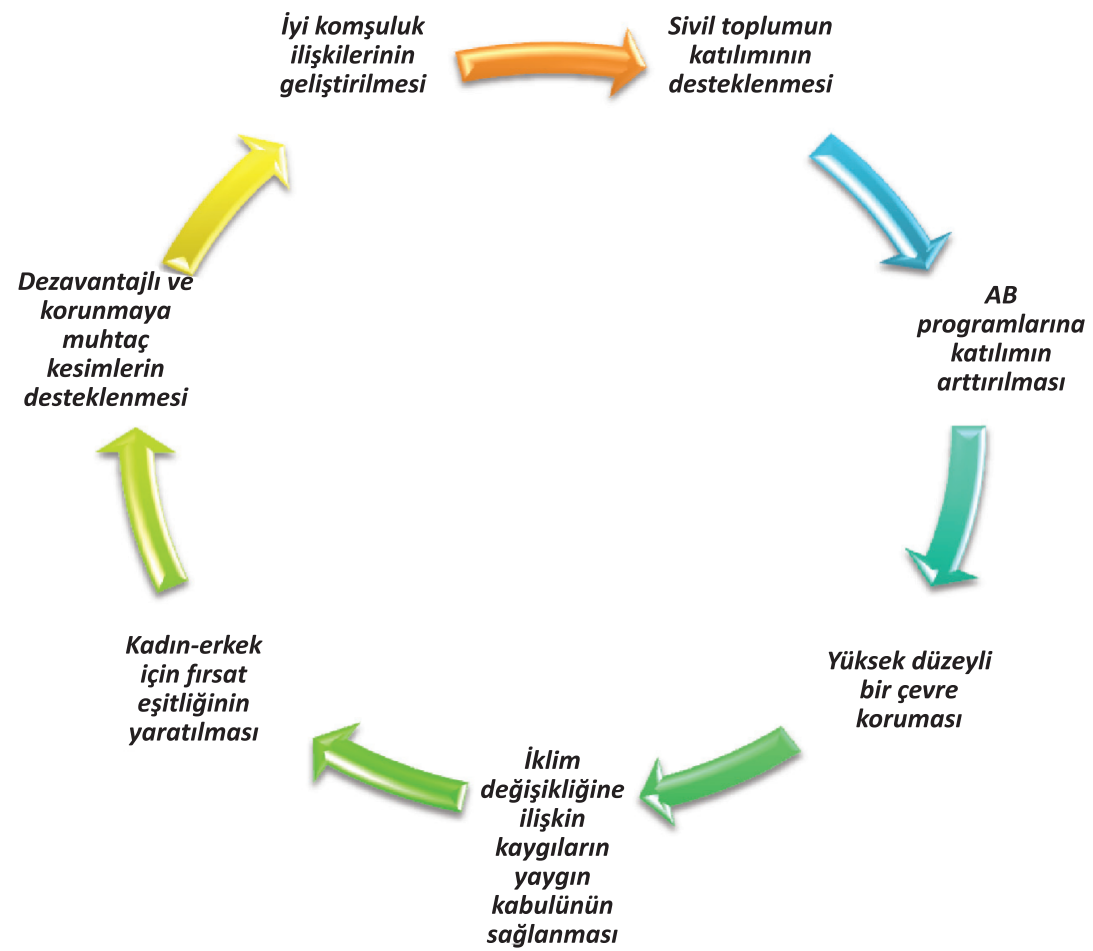

Kaynak: Çok-Yıllı Endikatif Planlama Belgesi (MIPD) 2011-2013, AB Bakanlığı Gayrı Resmi Türkçe Çeviri

Bu yatay öncelikler bağımsız olarak desteklenebildiği gibi diğer öncelik alanlarındaki programlar ve projelerin bir parçası olarak da ele alınabilmektedir. Bu öncelikler doğrultusunda, MIPD’ deki sektörler, Türkiye'nin üyelik sürecinde Kopenhag kriterlerini, özellikle siyasi kriterleri, tam anlamıyla sağlaması için süregelen zorluklar göz önünde bulundurularak seçilmiştir. Bununla birlikte, Türkiye'nin katılım çalışmaları kapsamında desteğe ihtiyaç duyduğu her alanın, gelecekteki üç yıl içerisinde MIPD altında finanse edilmesi mümkün olmadığı için öncelik, büyük etkiler yaratacak alanlara verilmiştir. ${ }^{28}$

28 Çok-Yıllı Endikatif Planlama Belgesi (MIPD) 2011-2013, AB Bakanlığı Gayrı Resmi Türkçe Çeviri, s. 9 
AB Komisyonu, 2011-2013 programlama dönemi için seçilen önceliklerin gerçekleştirilebilmesi amacıyla yardımlarını temel olarak aşağıda yer alan Şekil 6'daki sektörlere yoğunlaşttracaktır.

\section{Şekil 6: MIPD Belgesinin Yoğunlaşacağı Sektörler}

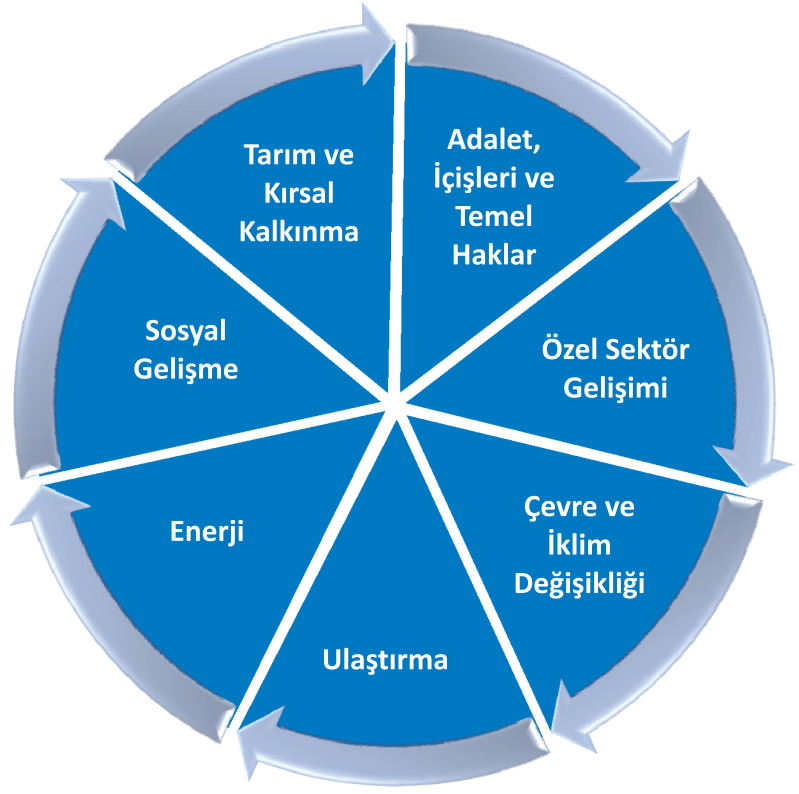

Kaynak: Çok-Yıllı Endikatif Planlama Belgesi (MIPD) 2011-2013, AB Bakanlığı Gayrı Resmi Türkçe Çeviri

Bu sektörleri desteklemeye yönelik mali yardımların, IPA programının I., III., IV. ve V. bileşenlerine sağlanan yardımlar kapsamında tahsisatı yapılmakta olup uygulamalar teknikyardım, eşleştirme, inşaat ve tedarik sözleşmeleri ile hibe programları aracılığıyla gerçekleştirilmektedir. Programlama ve uygulama aşamalarında, özellikle sosyoekonomik destek programları kapsamında cinsiyete ilişkin firsat eşitliği ve ayrım gözetmeme hususları dikkate alınmalıdır. Başta kamu hizmeti, yasama ve sosyo-ekonomik gelişmeyle ilgili konular olmak üzere, IPA çatısı altında programlaması yapılan tüm aktivitelerde azınlıkların ve korunmaya muhtaç grupların önceliklerinin göz önünde bulundurulması gerekmektedir. 
2011-201329 yılları için hazırlanan Çok Yıllı Endikatif Mali Çerçeve Belgesi'ne(MIFF) göre Türkiye'ye, katılım öncesi yardım kapsamında yaklaşık olarak 2616.9 Milyon Avro tutarında fon tahsis edilmiştir. Tahsis edilen bu miktardan, insan kaynaklarının geliştirilmesi bileşeni için 2011 yılında 77,60 Milyon Avro 2012 yılı için 89,93 Milyon Avro ve 2013 yılı için 96 Milyon Avro ayrılmıştr. ${ }^{30}$

MIPD, sosyal gelişme alanını temel olarak yoğunlaşılacak sektörlerden birisi arasında saymıştır. Sosyal gelişme ile ilgili bölümde Türkiye için işsizlik oranları ve kadınların işgücüne katılımının yüksekliğine değinilmiştir. Eğitim sisteminin ile işgücü piyasasının ihtiyaçlarının tam olarak örtüşmediği, köyden kente doğru göç, okula kayıt oranlarının düşük olması ve özellikle kızların ve kadınların okula devam oranının erkeklere göre çok daha düşük seviyede kalması temel sorunlar arasında sayılmıştır.

Belgede, Türkiye nüfusunun yoksulluk tehdidi altında olduğu belirtilmiş, özellikle çocuk ve gençler arasındaki yoksulluğun yetişkinlere göre çok daha fazla olduğu vurgulanmıştr. Engelliler, eski mahkumlar, eski hükümlüler, ülkesinde yerinden edilmiş insanlar (IDP'ler), Romanlar ve yüksek yoksulluk alanlarında ikamet edenlerle ilgili birçok kamu, özel ve sivil toplum kuruluşu bulunmasına rağmen, bireysel vakaların üstesinden gelecek kurumsal koordinasyon eksikliği bulunmakta olduğu belirtilmiş ve farklı kurum/ kuruluşlar arasındaki hizmetlerin çok parçalı bir yapı arz etmekte olduğu tespit edilmiştir.

\subsection{MIPD’de İnsan Kaynaklarının Geliştirilmesi Bileşeni}

IPA' nın IV. Bileşeni olan İnsan Kaynaklarının Geliştirilmesi Bileşeni, sosyal gelişme altında finanse edilecek ana öncelik olarak sayılmıştr. Bu bileşen altındaki yardımlar; eğitim, beceriler, hayat boyu öğrenme ve sosyal içermenin geliştirilmesi alanları ile temel vurgu, sağlık hizmetleri ve dezavantajlı grupların desteklenmesinde olmak üzere yoksullukla mücadele hususlarına ilişkin Avrupa 2020 Stratejisi önceliklerini teşvik etmeye yönelik olarak tahsis edilmektedir. ${ }^{31}$

29 Bu konuda geniş bilgi için bkz Çok Yıllı Endikatif Mali Çerçeve (MIFF): http://eur-lex.europa.eu/LexUriServ/LexUriServ.do?uri=COM:2009:0543:FIN:EN:PDF

30 Çok-Yılıı Endikatif Planlama Belgesi (MIPD) 2011-2013, AB Bakanlığı Gayrı Resmi Türkçe Çeviri, s. 12

31 Çok-Yılı Endikatif Planlama Belgesi (MIPD) 2011-2013, AB Bakanlığı Gayrı Resmi Türkçe Çeviri, s. 25 
IV. bileşen altında birinci hedef, Avrupa Sosyal Fonunun (European Social Fund-ESF) etkin uygulaması ile hem istihdam ve insan kaynaklarının gelişiminin hem de kurumsal yapılanma ve idari kapasitenin güçlendirilmesine yönelik olarak Türkiye ile, AB politikaları ve Avrupa 2020 Stratejisine ait parametrelerin yakınlaştırılmasıdır. Bu bağlamda aşağıdaki hususlar ana hedefler olarak belirlenmiştir ${ }^{32}$ :

- İşsizliğin azaltılması (özellikle kırsal kesimde yaşayan gençler için), kayıt dışı istihdam seviyesinin düşürülmesi ve özellikle kadınlar için istihdama katılım oranının arttrılması (önceden tarımda istihdam edilenler dâhil olmak üzere).

- İşgücü piyasası, eğitim ve öğretim ile sosyal içerme politika alanlarındaki bölgesel farklılıklara ilişkin stratejik yaklaşımların yanı sıra kaliteli ve ülke çapına yaygın aktif işgücü politikalarını etkin olarak uygulayabilen kamu istihdam hizmetlerinin modernize edilmesi ve güçlendirilmesi.

- Özellikle kızlara yönelik ortaöğretim/mesleki eğitiminin çekiciliğinin arttrılması; işgücü piyasalarının ihtiyaçlarına göre eğitim ve öğretimin uyarlanması.

- Kadınlar, gençler, engelliler ve yardıma muhtaç diğer kişilere daha fazla eğitim verilmesi ve bu grupların istihdam edilmesi yoluyla sosyal entegrasyon politikalarının güçlendirilmesi.

- Kadınların istihdama katımını teşvik etmek amacıyla, eğitim, öğretim, iş olanakları, çocuklar ve yaşlılar için günlük bakım imkânları sağlayan sosyal hizmetlerin koordinasyonu ile etkinliğinin arttrılması.

- Hayat boyu öğrenmeye ilişkin olarak uyumlu ve kapsamlı stratejilerin geliştirilmesi ve uygulanması yoluyla hayat boyu öğrenme imkânlarının geliştirilmesi.

32 Çok-Yıllı Endikatif Planlama Belgesi (MIPD) 2011-2013, AB Bakanlığı Gayrı Resmi Türkçe Çeviri, s. $26-27$ 
- Özellikle dezavantajlı kişilerin işgücü piyasasına entegrasyonunu teşvik etmek amacıyla işgücü piyasası ve sosyal koruma alanlarına yönelik olarak, kurumlar ve mekanizmalar arasında daha iyi bir işleyiş ve koordinasyonun temin edilmesi.

\section{IPA-I Geçiş Dönemi Desteği ve Kurumsal Yapılanma}

IPA uygulamasının en önemli bileşenlerinden birisi olan "Geçiş Dönemi Desteği ve Kurumsal Yapılanma" bileşeninden kamu kurum ve kuruluşları faydalanmaktadır. Müktesebat uyumu, kamu yönetimi reformu, adalet ve içişleri reformu, sivil toplumun gelişimi ve temel haklar, çevre politikası, eğitim ve sağlık sistemi reformu, yolsuzluğa karşı daha verimli ve etkili bir mücadele yürütülmesi ve mali kontrol gibi konular projeler yoluyla bu bileşen altnda finanse edilmektedir. IPA I bileşeninin uygulanmasından Avrupa Birliği Bakanlığı sorumludur. Bu bileşen altındaki fonlar ayrıca ülkemizin 2006 yılından beri katlım sağladığı AB Topluluk Program ve Ajanslarına katılımı desteklemektedir. Bu program ve ajanslar ülkeler arası işbirliği ve iletişimin geliştirilerek ortaklık bilinci, yenilikçilik ve girişimcilik anlayışının yerleşmesinin sağlanmasını hedeflemektedir. Vatandaşların, işletmelerin, sivil toplum kuruluşlarının, kamu kurumlarının bu programlara katılımı mümkündür. Bu başlık altında, 2007-2010 yılları için toplam 137 proje hazırlanmış olup programın toplam bütçesi 1,3 milyar avrodur; bu tutarın 928,7 milyon avrosu $A B$ hibe katkısı ve 422,8 milyon avrosu ise ülkemiz katkısından oluşmaktadır. ${ }^{33}$

IPA I - Geçiş Dönemi Desteği ve Kurumsal Yapılanma, Türkiye'nin katılım kriterlerini yerine getirmesinin desteklenmesine yöneliktir. IPA I kapsamında yardım, aşă̆ıdaki hususlar aracılığıyla sağlanabilmektedir:

1. Özellikle eşleştirme, kısa süreli eşleştirme ve Teknik Destek ve Bilgi Değişim Ofisi (TAIEX) vasıtasıyla, üye ülkeler veya uluslararası kuruluşlardan gönderilen kamu sektörü uzmanlarını kapsayan eğitim ve bilgi değişimi amaçlı idari işbirliği önlemleri,

33 http://www.abgs.gov.tr/index.php?p=5 
2. Kurumsal uzmanlığın güçlendirilmesi ve kurumsal yapılanmanın desteklenmesi amacıyla teknik yardım,

3. Çok taraflı bağımsız yabancı kuruluşları da içeren ve özellikle Avrupa Birliği norm ve standartlarına uyumun desteklenmesi amacıyla gerçekleştirilen düzenleyici altyapı yatırımları ${ }^{34}$,

4. Belirli tematik alanlardaki hedef grupların küçük ölçekli girişimlerinin desteklenmesi amacıyla hibe programları,

5. Avrupa entegrasyon sürecini güçlendirmek amacıyla destek faaliyetleri ${ }^{35}$.

Tablo 3: 2011-2013 Çok Yıllı Endikatif Mali Çerçeve Belgesine (MIPD) göre IPA Bileşen I için Mali Yardımların Yıllara Göre Dağılımı (Milyon Avro)

\begin{tabular}{|c|c|c|c|c|}
\hline Bileşen & $\mathbf{2 0 1 1}$ & $\mathbf{2 0 1 2}$ & $\mathbf{2 0 1 3}$ & Toplam \\
\hline $\begin{array}{c}\text { IPA I - Kurumsal } \\
\text { Yapilanma }\end{array}$ & 231,27 & 227,5 & 246,28 & 705,8 \\
\hline
\end{tabular}

Kaynak: Avrupa Birliği Entegrasyon Sürecini Destekleme Faaliyetleri, SEl rehberi, AB Bakanlığı, 2012, s. 7

IPA I bileşeni için stratejik referans, MIPD'dir. MIPD' de belirlenen, Bileşen I altında her bir öncelik alanı için mali tahsisat Tablo 4' te gösterilmiştir:

34 Bu alanda hedef, kilit düzenleyici kurumlardır ve kamu yönetimi reformuna ve $A B$ müktesebatına uyuma yönelik açıkça belirtilmiş bir strateji temelinde yürütülmektedir.

35 Avrupa Birliği Entegrasyon Sürecini Destekleme Faaliyetleri, SEI rehberi, AB Bakanlığı, 2012, s. 7 
Tablo 4: IPA Bileşen I için MIPD Öncelik Alanları

\begin{tabular}{|c|c|c|}
\hline & IPA Bileşen I için MIPD Öncelik Alanları & \\
\hline Öncelik 1 & Kopenhag siyasi kriterlerini tamamen karşılamaya yönelik ilerleme & $\% 15-25$ \\
\hline Öncelik 2 & Birlik müktesebatının üstlenilmesi ve uygulanması & $\% 45-65$ \\
\hline Öncelik 3 & AB-Türkiye Sivil Toplum Diyaloğunun geliştirilmesi & $\% 20-35$ \\
\hline Öncelik 4 & Destek faaliyetleri & $\% 3-5$ \\
\hline
\end{tabular}

Kaynak: Avrupa Birliği Entegrasyon Sürecini Destekleme Faaliyetleri, SEl rehberi, AB Bakanlığı, 2012, s. 7

\section{IPA -IV İnsan Kaynaklarının Geliştirilmesi}

Insan Kaynaklarının Geliştirilmesi Bileşeninin genel amacı, daha fazla ve daha iyi istihdam olanakları ve daha geniş bir sosyal uyum ile sürdürülebilir ekonomik büyüme yeteneğine sahip bilgi temelli ekonomiye geçişin desteklenmesidir. Söz konusu IPA bileşeninin kurumsal açıdan amacı ise, aday ülkeleri Avrupa İstihdam Stratejisi ve Lizbon Stratejisi çerçevelerinde Avrupa Sosyal Fonuna hazırlamak ve uygun yapı ile sistemleri kurmaktır. ${ }^{36}$

$B u$ alanda ülkemiz diğer aday ülkeler gibi, $A B$ uyum politikalarının uygulanması ve idaresine yönelik hazırlıklar, özellikle de Avrupa Istihdam Stratejisi çerçevesinde Avrupa Sosyal Fonu'na uyum hazırlıkları konularında desteklenmektedir. ÇSGB tarafindan koordinasyonu sağlanan "Insan Kaynaklarının Geliştirilmesi Operasyonel Programı" (IKG OP) kişi başı milli geliri Türkiye ortalamasının \% 75 'inin altında kalan bölgelerdeki istihdam kapasitesinin artrılması ve beşeri sermayenin güçlendirilmesini hedeflemektedir.

Bu çerçevede İstihdam, Eğitim ve Sosyal İçerme öncelik alanları olarak belirlenmiştir. İstihdam önceliğiyle özellikle gençlerin ve kadınların istihdama katlımının artrııması ve istihdamda sürekliliklerinin sağlanması esas alınmıştır. Bu öncelik kapsamında eğitim ve mesleki eğitim yoluyla istihdama katılım konusunda bir kamu bilinci

36 http://ikg.gov.tr/web/tr-tr/oppr.aspx 
oluşturulması da öngörülmüştür. Ayrıca kayıtlı istihdamın teşviki, daha etkin işgücü politikalarının uygulanması, daha kaliteli hizmet sağlanması ve kamu istihdam hizmetleri büyük önem taşımaktadır.

Eğitim önceliğiyle eğitim kalitesinin artırılması, başta kız çocukları olmak üzere her yaşta eğitim düzeyinin yükseltilmesi ve işgücü piyasası ile eğitim bağının kuvvetlendirilmesi amaçlanmaktadır. Hayat Boyu Öğrenme ile bu öğrenme imkânlarının yaygınlaştrılması ve iyileştirilmesi, iş̧̧i, işveren ve işletmelerin değişen şartlara uyum kabiliyetlerinin artrılması beklenmektedir. Sosyal iç̧erme önceliği çerçevesinde, dezavantajı kişilerin işgücü piyasasına ve sosyal korumaya erişimlerinin kolaylaştrılıması, işgücü piyasasına erişimlerinin önündeki engellerin kaldırılması hedeflenmektedir. ${ }^{37}$

\section{IPA-IV bileşeni iki şekilde uygulanmaktadır:}

\section{Operasyonlar (Şemsiye Projeler):}

Ulusal düzeyde faaliyetlerin yürütülmesi, kurumsal kapasitenin geliştirilmesi ve ulusal politikaların belirlenmesi amacıyla Milli Eğitim Bakanlığı, Türkiye İş Kurumu; Sosyal Güvenlik Kurumu gibi merkezde yer alan kamu kurum ve kuruluşları aracılığıyla "operasyon" olarak adlandırılan "şemsiye projeler" dir.

\section{Hibe Programları:}

Operasyonların (şemsiye projelerin) en önemli ayağını, yerel düzeyde ilgili tarafların kullanacağı hibe programları oluşturmaktadır. Hibe programları ile yereldeki kurumlara, sosyal taraflara, sivil toplum kuruluşlarına, üniversitelere, belediyelere, valiliklere, mevcut sorunlarını belirleme, söz konusu sorunlar için ortak çözüm önerileri geliştirme ve bunları hayata geçirme olanağı sunulmaktadır.

IKG OP kapsamında teknik yardım hariç dört öncelik (müdahale alanı) ve bu öncelikler alttnda on tedbir (alt hedef) belirlenmiştir. İKG Bileşeni kapsamında operasyon (şemsiye projeler) ve hibe projelerinin mali

37 http://www.abgs.gov.tr/index.php?p=5 
olarak desteklenmesi için, Operasyonel Programda belirtilen tedbirlere ve bu tedbirlerin altinda yer alan faaliyetlere uygun olması ile her tedbir için belirlenen göstergeleri sağlaması gerekmektedir. IKG OP' nin ulusal katkı dahil toplam bütçesi yaklaşık olarak 186 milyon avrodur (yıllık yaklaşık 55 milyon avro) ve ağırlıklı olarak kişi başına milli gelirleri Türkiye ortalamasının \% 75'inin altında kalan 12 Düzey II bölgelerinde (43 ilde) uygulanmaktadır. ${ }^{38}$

\subsection{Insan Kaynaklarının Geliştirilmesi Operasyonel Programı (iKG OP)}

Insan Kaynaklarının Geliştirilmesi Operasyonel Programı (iKG OP), insan kaynaklarının geliştirilmesi alanında IPA fonlarından yardım almak için oluşturulan programlamanın temelini belirlemektedir. Türkiye'nin istihdam, mesleki eğitim ve öğretim ile sosyal içerme alanlarında karşılaştı̆̆ı sorunlara yönelmeyi amaçlamaktadır. ÇSGB, Insan Kaynaklarının Geliştirilmesi (IKG) bileşeninden sorumlu program otoritesi olarak belirlenmiş ve Operasyonel Programı (OP) hazırlama görevi Bakanlığa verilmiştir.

IKG OP, Türkiye'nin 9. Ulusal Kalkınma Planı (UKP), Çok Yıllı Endikatif Planlama Belgesi (MIPD), Stratejik Uyum Çerçeve Belgesi (SÇB) ile uyumlu hazırlanmıştır. IKG OP'de belirtilen öncelikler ve önlemler; UKP, MIPD, SÇB ve ortak strateji belgelerinde yani Ortak içerme Belgesi (OiB) ve Ortak Değerlendirme Belgesi'nde (ODB) tanımlanmış temel sorunları ve itirazları yansıtmaktadır. SÇB, OiB ve ODB, Türkiye ve Avrupa Komisyonu tarafindan ortaklaşa olarak hazırlanmıştır. Program, 7 yıllık bir süreye sahip olmakla birlikte, mali bölümü 3 yıllık bir süre (2007-2009) için kesin olarak belirlenmiştir. MIPD ve Çok Yıllı Endikatif Mali Çerçeve (MIFF) ile uyumlu bir şekilde her yıl gözden geçirilmekte ve güncellenmektedir.

IKG OP'nin genel hedefi; "daha çok ve daha iyi işler ve daha fazla sosyal uyum ile sürdürülebilir ekonomik büyümeyi sağlayabilen bilgi temelli bir ekonomiye geçişi desteklemek" tir. IKG OP, teknik yardım ve kadınların 38 http://ikg.gov.tr/web/tr-tr/oppr.aspx 
işgücüne kathlımının artırıması, kamu istihdam hizmetlerinin idari kapasitesinin geliştirilmesi, işgücü piyasası ile eğitim arasındaki bağın kuvvetlendirilmesi, yasam boyu öğrenimin geliştirilmesi, eğitimin kalitesinin geliştirilmesi ve sosyal dışlanma riski ile karşı karşıya olan özel itina gösterilmesi gereken kişilerin entegrasyonu gibi konuları da kapsayan her bir öncelik için ilgili önlemleri de içeren beş öncelik belirlemiştir.

IKG OP, (MIPD'de) ve SÇB' de belirtilen yakınsama yaklaşımı ile paralel hazırlanmış olup, Türkiye'deki mevcut bölgesel farklılıkları azaltmaya katkıda bulunacak önlemleri desteklemeyi amaçlamaktadır. Böylece IKG OP' den gelen yardım, Türkiye'deki 26 İstatistiki Bölge Birimleri Sınıflandırması II' den (Bölgesel Sınıflandırma-IBBS) 12 IBBS bölgesine odaklanacaktır. Bu 12 bölgede kişi basına düsen Gayri Safi Yurtiçi Hasıla, (GSYH) Türkiye'nin ortalama kişi basına düsen GSYH' nin \% 75'inin altındadır. 12 BBS II bölgesinde SÇB, büyüme merkezi olabilme potansiyeline sahip 15 şehir belirlemiştir. Bu 15 "büyüme merkezi", seçilen 12 BBS bölgesinde gelişimle ilgili sinerjileri katkıda bulunmada kilit rol oynaması düşünülmektedir. 12 iBBS II bölgesindeki büyüme merkezlerinin dışında kalan bütün diğer alanlar, "art alan" olarak adlandırılmaktadır. 12 uygun iBBS II seviye bölgesi, aşağıda Şekil 7'deki Türkiye haritasında sarı renk ile gösterilmiştir ${ }^{39}$.

39 İnsan Kaynaklarının Geliştirilmesi Operasyonel Program Taslağı, Gayrı Resmi Türkçe Çevirisi, ÇSGB, s. 9 


\section{Şekil 7: Türkiye'de iвВS Bölgeleri}

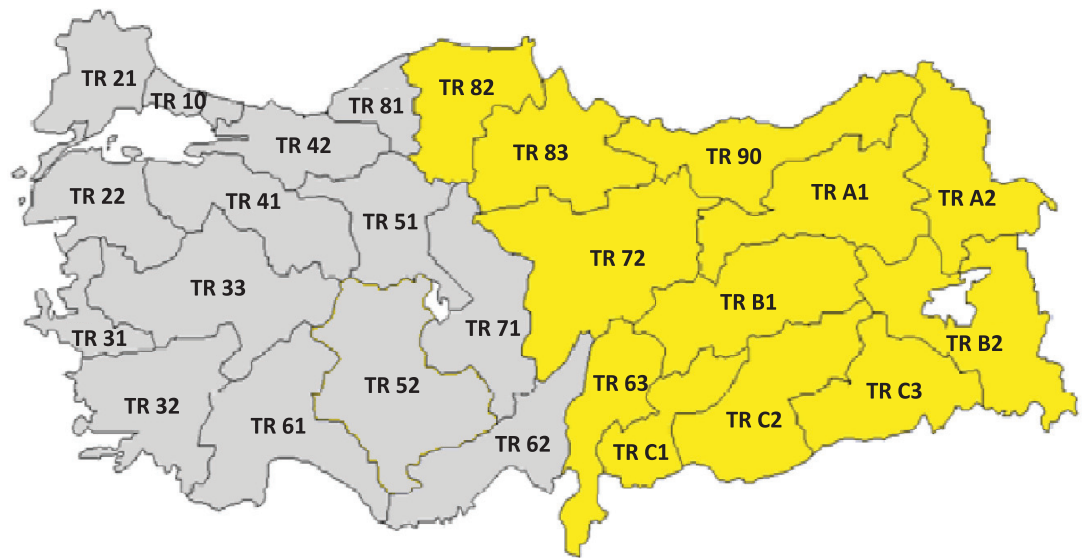

Kaynak: İnsan Kaynaklarııı Geliştirilmesi Operasyonel Program Taslağı, http://ikg.gov.tr/web/tr-tr/oppr.aspx

IKG OP, taslak aşaması sürecinde bütün ilgili tarafların görüşleri de alınarak bir ortaklık ilkesi çerçevesinde hazırlanmıştır. IKG OP' nin 5 bölümü bulunmaktadır.

Birinci bölümde Topluluk stratejisi çerçevesiyle birlikte ulusal politika ve sosyo-ekonomik bağlamı, ortaklık sürecini ve ön değerlendirme prosedürünü açıklamaktadır. Bölümün girişinde demografik ve makroekonomik bir durum değerlendirmesi yapılmakta ve bu bağlamda insan kaynaklarının geliştirilmesi hususu, ulusal belgeler yönüyle ve Avrupa Birliği'nin bu alandaki uygulamaları yönüyle ele alınmaktadır.

İkinci bölümde ise Türkiye'de insan kaynaklarının geliştirilmesi üzerine orta vadede bir ihtiyaç değerlendirmesini içermekte ve Güçlükler Zayıflıklar Tehditler Fırsatlar (GZTF) analizi ile Türkiye'nin stratejik önceliklerini ve yaklaşımını ortaya koymaktadır. Konu Sosyo-ekonomik durum, eğitim ve mesleki eğitim, yoksulluk ve sosyal dışlanmayla mücadele, özel itina gösterilmesi gereken kişilerin sosyal içermesini teşvik etme ve kurumsal kapasite yönüyle irdelenmiştir. Bölüm sonunda orta vadeli ihtiyaçlar ve temel sorunlar belirlenmiş ve GZTF analizi yapılmıştır. 
IKG OP'nin Stratejik öncelikleri aşağıda yer alan Şekil 8'de gösterilmiştir:

\section{Şekil 8: iKG OP'nin Stratejik Öncelikleri}

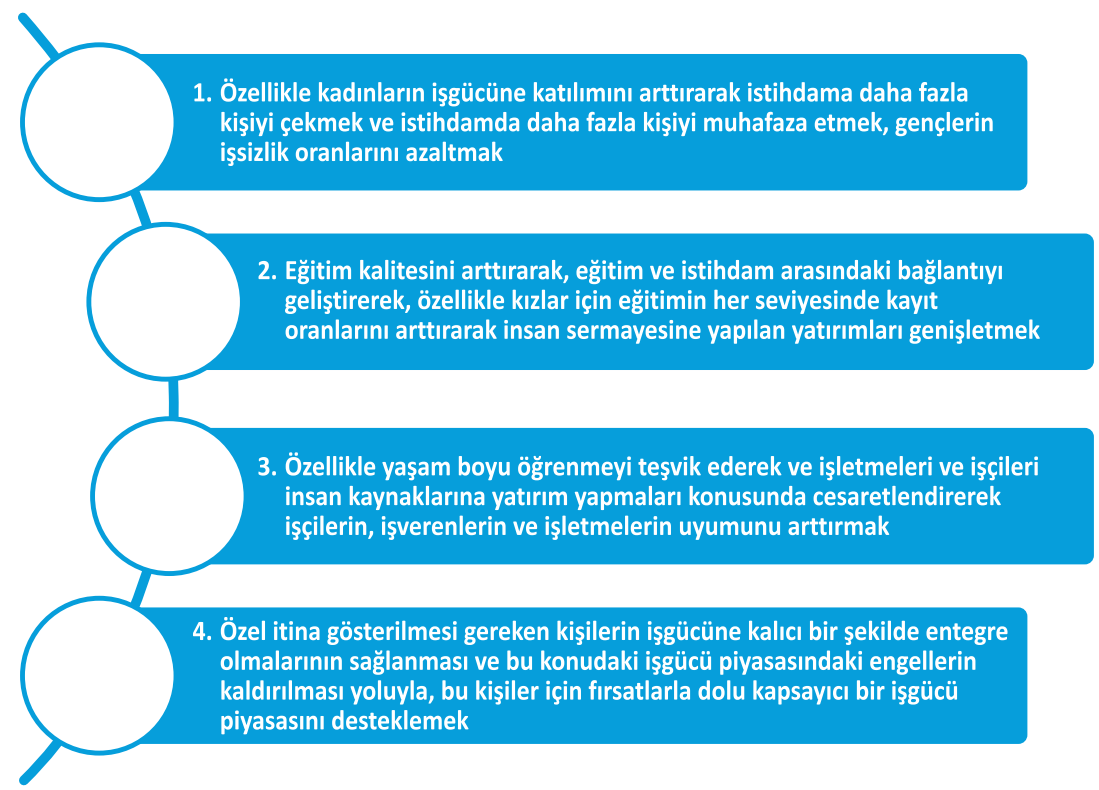

Kaynak: İnsan Kaynaklarının Geliştirilmesi Operasyonel Program Taslağı,

Gayrı Resmi Türkçe Çevirisi, ÇSGB, s. 98

Üçüncü bölüm, beş öncelik ekseni ile ilgili önlemleri içerecek şekilde IKG OP' nin program stratejisini özetlemektedir. Ayrıca, IV. bilesen kapsamında yatay konuların40 yardım programlaması hususunda nasıl ele alınacağı açıklamaktadır. Bu bölüm ayrıca, IPA' nın diğer yardım şekilleri ile birlikte sinerjileri ve tamamlayıcıları da içermektedir. Ana öncelik eksenleri ve alınacak tedbirler istihdam, eğitim, yasam boyu öğrenme yoluyla uyum yeteneğinin arttırılması, sosyal içerme ve teknik yardım başlıklarında tek tek tanımlanmış ve alınması gereken ve tedbirler belirlenmiştir. İKG OP'ye göre i̇stihdam sosyal güvenlik ile doğrudan ilişkilendirilmiş; sosyal içerme ekseni ile sosyal güvenlik arasında ise dolaylı bir ilişki kurulmuştur. Çalışmanın ilerleyen bölümlerinde bu iki öncelik ekseni detaylı olarak ele alınacak ve teknik yardım açıklanacaktır.

40 Daha önce de bahsedildiği gibi Türkiye'deki tüm IPA Programlaması için yatay konular olarak MIPD tarafindan önerilmiştir. 
Üçüncü bölümde her bir tedbir için özel amaç tanımlanmış, tedbirinin temelini teşkil eden özel amaç ortaya konulmuş ve uygulanacak tedbirin uygulanma sürecine ilişkin temellendirme yapılmıştr. Daha sonra desteklenebilecek faaliyetler ve proje seçim kriterleri belirlenmiştir. Son olarak fondan faydalanabilecek olan nihai faydalanıcılar ve projelerin yönelebileceği hedef gruplar tanımlanmış; ve izleme göstergeleri ile projelerin elde etmeyi amaçladığı çıktıların elde ediliş biçimleri ve çıktıların nasıl ölçüleceği ortaya konulmuştur.

IKG OP'nin dördüncü bölümünde ise, IPA Çok Yıllı Endikatif Mali Çerçeve (MIFF)' ye göre, bütün OP ve her bir öncelik ve önlem için tahsis edilen mali ödenek ele alınmıştir. MIFF uyarınca 2007-2013 periyodu için IKG OP' ye 299.7 Milyon Avro tahsis edilmiştir. IPA Uygulama Tüzüğünün 153.2 Maddesi uyarınca $A B$ katkısı her bir öncelik ekseni altındaki uygun harcamaların \%85'ini asmamalıdır. Hiçbir operasyon, öncelik ekseni altında belirlenenden daha fazla bir eş-finansmana konu olamamaktadır. Tüm öncelik eksenleri için $A B$ katkısı \%85, es finansman oranı ise \%15 olarak belirlenmiştir.

Besinci bölüm, IPA Uygulama Tüzüğü’nde belirtilen genel kurallarla uyum içinde olacak şekilde uygulama hükümlerini içermektedir. Ayrıca IV. Bileşenin idaresiyle alakalı belirli uygulama kurallarına da odaklanmakta; íKG OP'nin uygulama düzenlemeleri açıklanmaktadır. Bu kapsamda IKG OP'nin uygulaması, yönetimi, izlenmesi, değerlendirilmesi, operasyonların seçiminin yanı sıra bilgilendirme ve tanıtım faaliyetlerinin genel çerçevesi betimlenmektedir. ${ }^{41}$

41 Geniş bilgi için bkz: Human Resources Development, Operational Programme, Ministry of Labour and Social Security Republic of Turkey, s. 181-213 
Şekil 9: iKG OP Ana Öncelik Eksenleri

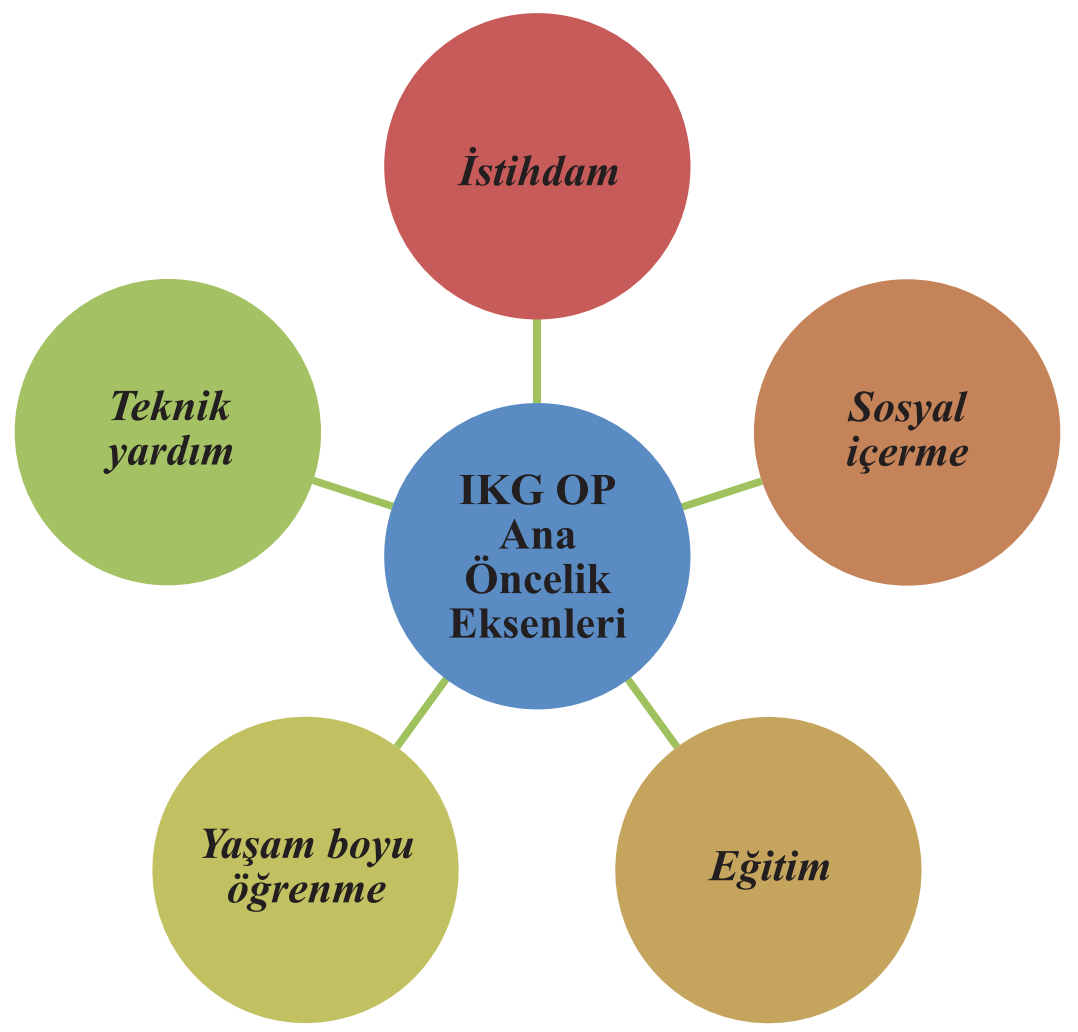

\subsection{IKG OP Ana Öncelik Eksenleri}

\subsection{1 İstihdam}

İstihdam alanında 4 adet tedbir belirlenmiştir. Bunlar aşağıdaki şekilde gösterilmiştir: 
Şekil 10: IKG OP' nin İstihdam Alanındaki Tedbirleri

4. Kamu istihdam hizmetlerinin

3. Kayıtlı istihdamın

kalitesinin artırılması teşvik edilmesi

2. Gençlerin istihdamının artırılması

1. Daha önce tarımda çalıșmakta olanlar dâhil olmak üzere, kadınların işgücüne katılımlarını teşvik etmek ve kadın istihdamını artırmak

Bu tedbirlerden Kayıtlı İstihdamın Teşvik Edilmesi tedbiri sosyal güvenlik alanı ile doğrudan ilgili iken Kamu istihdam hizmetlerinin kalitesinin artırılması ise dolaylı bir ilişkiye sahiptir. Bu alanlarda IKG OP, SGK'yı nihai faydalanıcılar arasında göstermiştir.

\subsubsection{Kayıtı İstihdamın Teşvik Edilmesi Tedbiri}

$\mathrm{Bu}$ tedbirin amacı, Sosyal Güvenlik Kurumu'nun kapasitesinin güçlendirilmesi ile sosyal taraflarla ilgili kamu kurum ve kuruluşlarının koordinasyonunun artırılması yoluyla kayıtı istihdamın teşvik edilmesi olarak tanımlanmıştır. ${ }^{42} \mathrm{Bu}$ alanda proje yapılması halinde fonlanabilecek faaliyetler aşağıda yer alan Şekil 11'de yer almaktadır.

Projelerin seçim kriterleri, proje ile kayıtlı istihdamda sağlanacak artış arasındaki bağlantının açıkça ortaya konması ve projenin hedef gruplara nasıl odaklanacağının gösterilmesi olacaktır. SGK, bu tedbirin nihai faydalanıcıları arasında sayılmıştır. Projelerin hedef grupları ise kayıt dışı çalışanlar ve bunların bakmakla yükümlü oldukları kişiler, düşük eğitim düzeyine sahip kayıt dışı olarak çalışan kadınlar, ilgili kurumların personeli ve sosyal taraflar olarak belirlenmiştir.

42 İnsan Kaynaklarının Geliştirilmesi Operasyonel Program Taslağı, Gayrı Resmi Türkçe Çevirisi, ÇSGB, s. 101 


\section{Şekil 11: Kayıt dışı İstihdam Alanında Fonlanabilecek Faaliyetler}

Gereken bölgeler ve/veya sektörlerde, bu tedbir altındaki uygulamaları yönlendirecek nitelikte olmak üzere kayıt dışı istihdama yönelik olarak saha araştırmaları/işgücü piyasası analizleri

Daha önce kayıtlı istihdam alanında uygulanmış olan projelerin ve proje değerlendirmelerine devam edilmesi

Kayıt dışı istihdamla mücadeleye yönelik olarak bir Ulusal

Stratejinin hazırlanması

Kayıtlı istihdamın birlikte teşvik edilmesi için sosyal ortakların katılımıyla yerel istihdam işbirliklerinin kurulması

Kayıt dışı istihdamla mücadele yollarının öğretilmesi ve aynı zamanda ulusal stratejinin uygulanmasına ilişkin olarak SGK ve sosyal taraflara yönelik eğitim faaliyetleri ve kayıtlı istihdamın önemine ilişkin bilinç artırma faaliyetleri

SGK ve Maliye Bakanlığı, ÇSGB Teftiş Kurulu, Sanayi ve Ticaret Bakanlığı gibi diğer ilgili kurumların merkezi/yerel düzeydeki teftiş kapasitelerinin güçlendirilmesi

Kaynak: Human Resources Development, Operational Programme, Ministry of Labour and Social Security Republıc of Turkey, s. 119

\subsubsection{Kamu İstihdam Hizmetlerinin Kalitesinin Artırılması Tedbiri}

İstihdam alanında sayılan dördüncü tedbir olan Kamu İstihdam Hizmetlerinin Kalitesinin Arttrılması Tedbirinin ise sosyal güvenlik alanı ile dolaylı bir ilişkisi bulunmaktadır. Bu tedbir IKG OP tarafindan özellikle idari kapasitenin güçlendirilmesi yoluyla kamu istihdam hizmetlerinin kalitesinin ve etkinliğinin artırıması olarak tanımlanmıştır. Nihai faydalanıcılar arasında ÇSGB ve İ̧KUUR'un yanı sıra ilgili kamu kurumları arasında SGK da sayılmıştır. ${ }^{43}$

\subsubsection{Sosyal iç̧erme}

Sosyal içerme başlığının sosyal güvenlik ile dolaylı bir ilişkisi bulunmaktadır. Bu başlıkta ana öncelik ekseni, özel itina gösterilmesi gereken kişilerin işgücüne dâhil olmalarının sürdürülebilir hale getirilmesi ve işgücü piyasasındaki tüm ayrımcılık türleri ile mücadele

43 Bu bölüm ile ilgili daha fazla bilgi için bkz: Human Resources Development, Operational Programme, Ministry of Labour and Social Security Republıc of Turkey, s. 121-122 
edilmesi amacıyla gereken imkânları sağlayarak içermeci bir işgücü piyasasının teşvik edilmesi olarak belirlenmiştir. Bu öncelik ekseni ile ilgili olan SGK personeli de hedef gruplar arasında sayılmıştır. ${ }^{44}$

Özel itina gösterilmesi gereken kişiler, Özürlüler, gecekondu bölgelerinde yasayanlar da dâhil olmak üzere yoksul olan veya yoksulluk riski ile karsı karsıya olan kişiler, yerinden olmuş kişiler (IDP45), eski hükümlü ve tutuklular MIPD' de "Roma" olarak atffta bulunulan özel itina gösterilmesi gereken kişiler, çalışan çocukların aileleri/ebeveynleri olarak tanımlanmıştır.

\section{Bu öncelik ekseniyle ilgili iki adet tedbir belirlenmiştir. Bunlar:}

1. Özel itina gösterilmesi gereken kişilerin istihdam edilebilirliğinin artırılması, işgücü piyasasına erişimlerinin kolaylaştırılması ve işgücü piyasasına girişlerinin önünde yer alan engellerin ortadan kaldırılması,

2. Özellikle özel itina gösterilmesi gereken kişilerin işgücü piyasasına dâhil olmalarının kolaylaştırılması amacıyla işgücü piyasası ve sosyal koruma alanlarındaki kurumlar ve mekanizmalar arasında daha iyi bir işleyiş ve koordinasyon sağlanmasıdır

\section{Birinci tedbir kapsamında desteklenebilecek faaliyetler aşağıdaki gibidir:}

- Özel itina gösterilmesi gereken tüm kişilerin istihdam edilebilirliğinin artırılmasını amaçlayan Aktif İşgücü Piyasası Programları (AIPP) ve mesleki eğitimler,

- İşgücü piyasasına erişimlerinin kolaylaştırılması amacıyla özürlüler, eski hükümlüler ve tutuklulara yönelik rehabilitasyon programları,

- Özel itina gösterilmesi gereken kişilere yönelik önyargıların ortadan kaldırılmasını amaçlayan farkındalık arttırıcı faaliyetler,

\footnotetext{
44 Bu bölümün tamamına erişmek için bkz: Human Resources Development, Operational Programme, Ministry of Labour and Social Security Republıc of Turkey, s. 149-158

45 Internally displaced persons
} 
- Özel itina gösterilmesi gereken kişilerin istihdam ve sosyal koruma alanlarındaki kamu hizmetlerine erişim konularında bilgilendirilmelerini amaçlayan farkındalık arttırıcı faaliyetler.

- Özel itina gösterilmesi gereken kişiler için rehberlik ve danışmanlık hizmetleri ${ }^{46}$

Bahsedilen birinci tedbirin nihai faydalanıcıları arasında SGK da bulunmaktadır.

\section{ikinci tedbir ile ilgili olarak ise finansmanı yapılabilecek faaliyetler arasında:}

- AB'deki iyi uygulama örnekleri ile uyumlu olarak istihdam ve sosyal koruma alanlarındaki kamu hizmetlerinin kaliteli bir biçimde sunumuna yönelik olarak personelin eğitilmesi,

- İşgücü piyasası karsısında özel itina gösterilmesi gereken kişilerin durumu (sosyal güvenlik ve sağlık sistemlerine kayıtlı olunması, sosyal hizmetlerden yararlanıp yararlanılmaması, eğitim düzeyi, yas, mesleki nitelikler vs.) ile ilgili olarak mevcut tüm veri tabanlarından sağlanan bilgi akısının tek bir veri tabanında birleştirileceği merkezi/ yerel düzeyde ortak bir veri tabanının, izleme ve analiz sistemlerinin kurulması sağlanacağı belirtilmiş; söz konusu ortak veri tabanının, çapraz kontroller yapılabilmesi, hizmetlerin ve kaynakların etkinliğinin artırılması ve kötüye kullanımların önlenmesi amacıyla sivil toplum kuruluşları ve yerel makamlar da dâhil olmak üzere tüm ilgili kurumlarca kullanılabileceği,

- Ortak veri tabanının oluşturulması, kullanılması ve uygulanmasına ilişkin personele eğitim verilmesi,

- Sosyal koruma kurumları, STK'lar ve yerel idareler arasında merkezi ve yerel düzeyde ortaklıkların oluşturulması,

- Daha iyi ilişkiler kurulması ve özel itina gösterilmesi gereken kişiler için kaliteli hizmetler sağlanması amacıyla NLP eğitimi verilmesi sayıımıştr. ${ }^{47}$

46 Bu bölüm ile ilgili daha fazla bilgi için bkz: Human Resources Development, Operational Programme, Ministry of Labour and Social Security Republıc of Turkey, s. 152

47 Bu bölüm ile ilgili daha fazla bilgi için bkz: Human Resources Development, Operational Programme, Ministry of Labour and Socıal Security Republıc of Turkey, s. 156 


\section{SGK birinci tedbirin olduğu gibi ikinci tedbirin de nihai faydalanıcıları arasında gösterilmiştir.}

\subsubsection{Teknik Yardım}

IKG OP'nin beşinci ana öncelik ekseni ise teknik yardımdır. Teknik yardımın amacı, IKG OP' nin koordinasyonu, kontrolü ve uygulamasını geliştirmek, ilerideki programlama, izleme, değerlendirme ve uygulama süreçlerinde OP Program Otoritesine ve ilgili kurumlara destek olmak olarak tanımlanmıştır.

Teknik yardım aracı, programdan maksimum düzeyde fayda sağlanması için etkili uygulama düzenlemeleri kurulması yoluyla $\mathrm{OP}^{\prime}$ nin uygulanmasını desteklemektir. Programın etkili yönetimi ve idaresinin sağlanması için bu öncelik altındaki faaliyetler; kapasite artırma, kolaylaştırma, network geliştirme, izleme komitesine yardımcı olma, proje başvurularının değerlendirilmesi, tavsiye ve rehber kuralları, uzmanların eğitimi, izleme, promosyon ve yayınlama, değerlendirme, strateji ve yıllık raporların hazırlanması, ortaklık kurulması, araştırmalar, çalışmalar ve faaliyetlerin yayılması konularını içermektedir.

Bu öncelik, uygulama sürecinde yer alacak ilgili kurum ve kuruluşların üyelerine bilgi ve eğitim sağlayarak yatay ilkelerin uygulanmasını desteklemektedir. Kadın ve erkek arasında eşit firsatlar sağlanmasına yönelik izleme, yatay bir öncelik olarak, rehber ve göstergeler geliştirilmesi, araştrma ve çalışmalar ve bilgi faaliyetlerini gerektirmektedir. Proje yürütücülerinin (STK'lar da dâhil olmak üzere) kapasitelerinin artırılması ve istihdam, eğitim, yoksullukla mücadele ve sosyal içerme alanlarındaki ilgili ulusal ve yerel aktörler arasında ortaklık kuran aktiviteler de desteklenmektedir. Teknik yardım ayrıca, değerlendirme faaliyetleri ve çalışmaların ve analizlerin hazırlanması faaliyetlerini de içermektedir.

Teknik yardım ana öncelik ekseninde 3 adet tedbir tanımlanmıştır. Bunlar:

- Yönetim, Uygulama, İzleme, Kontrol, Değerlendirme ve Yayma 
faaliyetlerinin desteklenmesi

- Nihai faydalanıcıların hazmetme kapasitelerinin geliştirilmesi için destek

- Bilgi ve yayım faaliyetlerinin desteklenmesi. ${ }^{48}$

\subsubsection{IKG OP Belgesinin Yatay Konuları}

IKG OP’nin Üçüncü bölümün son kısmında tıpkı MIPD belgesinin yatay konuları gibi, IKG OP'nin yatay konuları ele alınmıştı. OP uygulaması, Türkiye için MIPD doğrultusunda, 2007-2013 dönemindeki IPA desteğinin temel yatay ilkelerinin yerine getirilmesine katkı sağlaması düşünülmektedir. Bunlar:

- Cinsiyet Eşitliği-Yapısal yardım adı altında finanse edilen tüm politika ve uygulamaların zorunlu bir bölümüdür

- Sürdürülebilir Kalkınma \& Çevrenin Korunması

- Sivil Toplumun Katilımı

- Coğrafik, Sektörel ve Tematik Yoğunlaşma

- Özel İtina Gösterilmesi Gereken Kişiler Sorunu

- İyi Yönetimdir ${ }^{49}$.

\section{Sonuç}

Bu çalışmada, AB'den IPA kanalıyla alınan yardımların sosyal güvenlik boyutu ele alınmıştır ve AB projelerine kaynaklık eden IPA belgelerinin sosyal güvenliğe yaklaşımı ortaya konulmaya çalışılmıs; ayrıca sosyal güvenlik alanında proje yapılabilecek olası alanlar incelenmiştir.

Bu bağlamda Türkiye'nin $A B^{\prime} y e$ üyelik süreci ele alınmış ve adaylıkla birlikte gelen mali yardımlar değerlendirilmiştir. 2007 den sonra tek başlık altında birleştirilen Katılım Öncesi Mali Yardımlar (IPA), ÇokYıllı Endikatif Planlama Belgesinin (MIPD), belirlediği öncelikler çerçevesinde dağıtılmaya başlanmıştır. Çalışmada bu öncelikler ile sosyal güvenliğin kesiştiği noktalar ele alınmıştı. Sosyal güvenlik alanında IPA-I Geçiş Dönemi Desteği ve Kurumsal Yapılanma Bileşeni vasıtasıyla ve IPA-IV İnsan Kaynaklarının Geliştirilmesi Bileşeni kapsamında mali yardımlardan yararlanmak mümkündür.

48 Bu bölüm ile ilgili daha fazla bilgi için bkz: Human Resources Development, Operational Programme, Ministry of Labour and Socıal Security Republıc of Turkey, s. 157-164

49 Geniş bilgi için bkz: Human Resources Development, Operational Programme, Ministry of Labour and Socıal Security Republıc of Turkey, s. 164-168 
Insan Kaynaklarının Geliştirilmesi Operasyonel Programı (IKG OP) ise sosyal güvenlik alanı ile ilgili proje yapılabilecek en geniş alanı ve mali yardım miktarını içermektedir. Bu temel nitelikteki belge de sosyal güvenlik çerçevesinde detaylı olarak incelenmiştir. Çalışma sonunda AB Mali Yardımlarının en üst noktadan başlayarak en alt noktaya kadar kaydettiği aşamalar aşağıda yer alan $\boldsymbol{A B}$ Mali Kaynakları Ağacında özetlenmiştir.

AB Mali yardımlarının, son yıllarda bilinirliği önemli ölçüde artmıştır. Bu çalışmanın sonucunda sosyal güvenlik alanındaki mali yardımların incelenmesi ve bilinilirliğinin arttrılması hedeflenmiştir. Özellikle önümüzdeki yıldan itibaren AB'de 2014-2020 Mali Planının devreye girmesi ile birlikte yeni bütçe döneminde $A B$ Mali yardımları ve projelerinden en üst seviyede yararlanmak, Türkiye' de sosyal güvenliğin gelişimine büyük katkı sağlayacaktır.

\section{Şekil 12: AB Mali Kaynakları Ağacı}

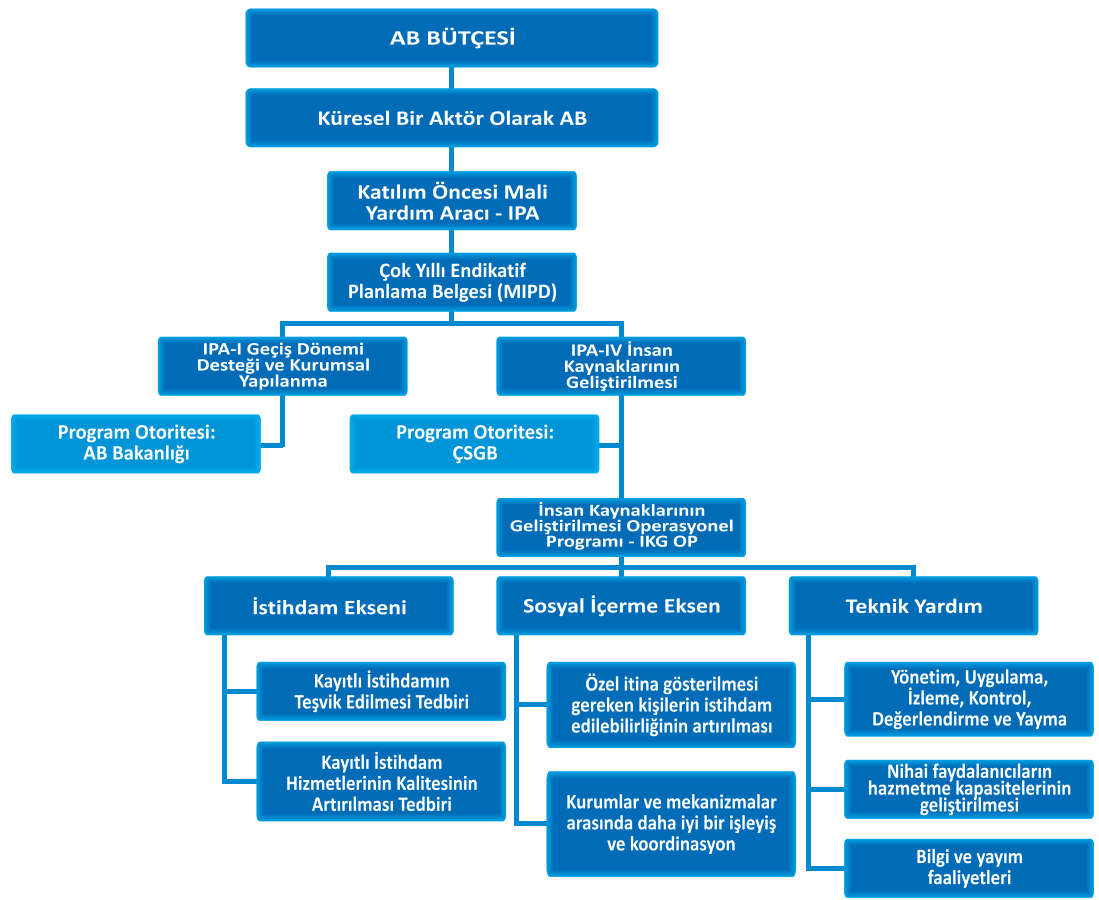




\section{Kaynakça}

BíLici Nurettin, Avrupa Birliği ve Türkiye, Seçkin Yayınevi, Güncelleştirilmiş 5. Baskı, Ankara 2012

Avrupa Birliği Bakanlığı, http://www.abgs.gov.tr/index.php?p=5

(Erişim Tarihi: 23.09.2013)

AB Bakanlığı, Avrupa Birliği Entegrasyon Sürecini Destekleme Faaliyetleri, SEI rehberi, , 2012, http://92.45.27.73/sei/images/ userManuals/Guide\%20for\%20SEI.pdf

AB Bakanlığı, Çok-Yıllı Endikatif Planlama Belgesi (MIPD) 2011-2013, AB Bakanlığı Gayrı Resmi Türkçe Çeviri,

Avrupa Birliği Türkiye Delegasyonu, http://www.avrupa.info.tr/tr/abve-turkiye.html

(E.T. 20.09.2013)

Avrupa Birliği Türkiye Delegasyonu, http://www.avrupa.info.tr/tr/ ab-mali-destegi/neden-ab-mali-destegi/ueyelik-kriterleri-kopenhagkriterleri.html

(E.T. 20.09.2013)

Avrupa Birliği Türkiye Delegasyonu, http://www.avrupa.info.tr/tr/ fundingopportunities/priorities.html

(E.T. 20.09.2013)

Avrupa Birliği Türkiye Delegasyonu, http://www.avrupa.info.tr/tr/ funding-opportunities/how-to-apply.html

(E.T. 21.09.2013)

Avrupa Birliği Türkiye Delegasyonu, http://www.avrupa.info.tr/tr/ avrupa-takimi/nasil-uygulanir/hizmet-soezlesmeleri.html

(E.T. 20.09.2013)

Avrupa Birliği Türkiye Delegasyonu, http://www.avrupa.info.tr/tr/ avrupa-takimi/nasil-uygulanir/supply-contracts.html

(E.T. 20.09.2013)

Avrupa Birliği Türkiye Delegasyonu, http://www.avrupa.info.tr/tr/ 
avrupa-takimi/nasil-uygulanir/hibeler.html

(E.T. 20.09.2013)

Avrupa Birliği Türkiye Delegasyonu, http://www.avrupa.info.tr/tr/ avrupa-takimi/nasil-uygulanir/eslestirme.html

(E.T. 20.09.2013)

Avrupa Komisyonu, http://ec.europa.eu/budget/mff/index_en.cfm (E.T. 13.09.2013)

Çalışma ve Sosyal Güvenlik Bakanlığı $A B$ Koordinasyon Dairesi Başkanlığı, http://ikg.gov.tr/web/

(E.T. 03.09.2013)

Çalışma ve Sosyal Güvenlik Bakanlığı, İnsan Kaynaklarının Geliştirilmesi Operasyonel Program Taslağı, Gayrı Resmi Türkçe Çevirisi, http://ikg. gov.tr/Portals/0/IKGOPv3TR.pdf

European Commission, European Commission proposal for the 20142020 Multiannual Financial Framework, http://ec.europa.eu/budget/ library/biblio/publications/2011/mff2011/MFF_2011_en.pdf (E.T. 05.09.2013)

European Commission A new focus to EU assistance for enlargement, ,2009http://ec.europa.eu/enlargement/pdf/publication/ipa_ brochure_2009_en.pdf

European Commission, Multi-Annual Indicative Financial Framework For 2011-2013, http://eur-lex.europa.eu/LexUriServ/LexUriServ. do?uri=COM:2009:0543:FIN:EN:PDF

Ministry of Labour and Social Security Republic of Turkey, Human Resources Development, Operational Programme, http://ikg.gov.tr/ Portals/0/Revised\%20HRD\%200P3.pdf 